\title{
The diversity and composition of moth assemblages of protected and degraded raised bogs in Ireland
}

\author{
CIARA FLYNN, ${ }^{1,2}$ CHRISTINE T. GRIFFIN, ${ }^{1}$ JOHN COLL ${ }^{3}$ and \\ CHRISTOPHER D. WILLIAMS ${ }^{4}{ }^{1}$ Department of Biology, Maynooth University, Maynooth, Co. \\ Kildare, Ireland, ${ }^{2}$ National Parks and Wildlife Service, Department of Arts, Heritage and the Gaeltacht, Wicklow \\ Mountains National Park, Laragh, Co. Wicklow, Ireland, ${ }^{3}$ Department of Geography, Maynooth University, Maynooth, \\ Co. Kildare, Ireland and ${ }^{4}$ School of Natural Sciences and Psychology, Liverpool John Moores University, Liverpool, UK
}

Abstract. 1. Peatlands are globally important habitats, which act as net carbon stores. As a result of drainage, peat extraction and agricultural intensification, raised bogs in the midlands of Ireland are a diminishing and increasingly fragmented peatland habitat. A network of protected sites has been established, which is intended to represent the best abiotic and plant community systems.

2. Lepidoteran communities are an important component of raised bog biodiversity and may be useful as biodiversity indicators, yet they are a neglected area of research.

3. We address this by surveying night-flying macro-moths on six protected and six degraded raised bogs to establish whether there is a distinct moth fauna associated with the wettest areas of protected sites by comparing them to assemblages found on degraded sites where this wet habitat has been lost.

4. In general, differences between moth assemblages on protected and degraded raised bogs are rather subtle, with assemblages on both site types generally similar. But, a number of species were found to be associated with protected sites, three of which are bog-associated species of conservation concern and may be particularly vulnerable due to the continuing loss of the wettest areas of raised bogs.

5. Degraded sites were found to harbour a significant number of bog-associated species of conservation concern and may have a role to play in peatland invertebrate conservation, hitherto undervalued. To determine this, further research is required to describe the invertebrate fauna of these sites and of marginal areas of protected sites.

Key words. biodiversity, biodiversity indicators, degraded sites, invertebrate conservation, lepidoteran communities, moths, protected sites, raised bogs, Natura 2000, Habitats Directive.

\section{Introduction}

Most peatlands are important net carbon stores (Dise, 2009), but human impacts such as drainage for agriculture, cattle ranching, forestry, peat extraction, infrastructure

Correspondence: Ciara Flynn. Department of Arts, Heritage and the Gaeltacht, National Parks and Wildlife Service, Wicklow Mountains National Park, Kilafin, Laragh, Bray, Wicklow, A98 K286, Ireland, Tel.: + 353 (0)404 45800 E-mail: Ciara.Flynn@ ahg.gov.ie developments, pollution and fires are important causes of degradation globally, which continue today (RenouWilson et al., 2011). Peatlands cover more than 4 million square kilometres worldwide, with $80 \%$ of the peatland area situated in temperate-cold climates in the northern hemisphere (Limpens et al., 2008). Raised bogs in Ireland are dome-shaped bodies of peat, which started to develop at least 7000 years ago, chiefly in basins or shallow lakes formed due to impeded drainage, after the last glaciation (Mitchell, 1990). On raised bogs in good condition, the water table remains close to the surface 
throughout the year, with much of the rainfall held by the living and partly humified Sphagnum moss layer (the acrotelm) which carpets the bog. Bog habitat with a peat-forming acrotelm is called 'active raised bog' and is a priority habitat for conservation under the European Union Habitats Directive (Council of the European Communities, 1992). Although generally regarded as species-poor systems, raised bogs are nonetheless important reservoirs of biodiversity as they contain uniquely adapted plant and animal species not found elsewhere (Renou-Wilson et al., 2011). Hence, it is these distinctive species which are most important to biodiversity at a regional level.

Much of the central limestone plain of Ireland was formerly characterised by large raised bog complexes. Some have historically been cut away entirely through exploitation as a domestic fuel source and have largely been reclaimed as agricultural grassland (Foss et al., 2001). The surface of a number of remaining bog complexes has been extensively cut over, with the extracted peat being used for commercial applications including domestic fuel production, fuel for electricity generating stations and as a growing medium in horticulture. Such bogs, where the surface has been stripped and is either bare or partly revegetating, are classified as secondary degraded bog (Fernandez et al., 2014).

Consequently, remaining areas of relatively intact bog, which have not been cut over, are mainly small remnants of once larger bog complexes and contain both active (peat forming) and degraded (not peat forming) raised bog habitats. The conservation status of active raised bog habitat in the Republic of Ireland has recently been assessed as 'bad' and the overall trend of this habitat is 'declining' (NPWS, 2013 ${ }^{1}$ ). This assessment is based on historic losses and ongoing declines due to peat extraction and continued drying, shrinking and slumping of the bog structure (NPWS, 2013). There has been a $99 \%$ loss of this habitat type and, for example in 2012, only an estimated 1639 ha remained nationally (DAHG, 2014). Irish midland raised bogs are assigned to the temperate, oceanic bog type associated with NW Europe (Cross, 1990; Kelly, 1993). Such bogs formerly occurred on a large scale in the UK, the Netherlands, Denmark and north-west Germany, as well as Ireland. But, widespread industrial peat cutting has greatly reduced the number of intact bogs of this type and the best remaining relatively intact examples are now found in Ireland (Schouten et al., 1992). Irish raised bogs are therefore globally important as they represent, in relative terms, the finest examples of their type

\footnotetext{
${ }^{1}$ NPWS is the National Parks and Wildlife Service, part of the Department of Arts, Heritage and the Gaeltacht (DAHG), one of whose statutory functions is to secure the conservation of wildlife and to promote the conservation of biological diversity in the Republic of Ireland.
}

(Kelly, 1993) and therefore Ireland has an international responsibility to conserve them.

In Ireland, 53 sites containing active raised bog habitat have been designated as Special Areas of Conservation (SACs) (DAHG, 2014), part of the European Natura 2000 conservation network (Council of the European Communities, 1992). Designation of raised bog SACs was based on plant community associations within habitats and hence did not directly consider the conservation of their invertebrate fauna due to limited taxonomic and distribution knowledge of these groups (Hernandez-Manrique et al., 2012). The aim of SACs selected by habitat is to protect species occupying those habitats in a so-called 'coarse filter' approach (Hunter, 2005). This approach seeks to conserve a representative array of regional habitats, thereby also conserving the majority of species within the region. It is complemented by the 'fine filter' approach where sites are selected to conserve specific species, in particular, certain bird species listed under the European Birds Directive and other non-bird wild fauna (largely vertebrates) and flora listed under Annex II of the Habitats Directive (Cardoso, 2012). Studies have found that the 'coarse filter' approach is not fulfilling its promise in relation to certain invertebrates, especially when fine-scale habitat structural diversity, known to be important to invertebrates, is not taken into account (Davies et al., 2007).

There is a growing recognition of the need to include invertebrates, an important component of peatland biodiversity (Cross, 1990), in planning and assessment of peatland conservation measures (van Duinen et al., 2003). Due to the impracticality of monitoring the total invertebrate fauna (Sauberer et al., 2004), even in species-poor habitats such as active and degraded raised bog, surrogate species or biodiversity indicators are needed to act as proxies for other less well-known taxa (McGeoch, 1998). Consequently, a number of invertebrate species or assemblages have been used or proposed as peatland biodiversity indicators, including carnivorous ground beetles (Williams et al., 2014), hoverflies (Speight et al., 2002) and aquatic macroinvertebrates (Hannigan \& Kelly-Quinn, 2012).

Based on criteria developed by Speight (1986), nightflying macro-moths which are attracted to light (hereafter referred to as moths) appear to have good potential as biodiversity indicators. In general, species can be reliably determined without undue effort. They are extensively recorded by amateur naturalists so that their Irish and European distributions are well known (Karsholt \& van Nieukerken, 2013; Tyner, 2014) and there is a reliable national species list (Bond et al., 2006). The biologies of many species are sufficiently well known so that their habitats can be defined (Bond \& Gittings, 2008; Waring \& Townsend, 2009) and they have potential for detection of site attributes that cannot be more easily detected using either vertebrates or higher plants (Bond \& Gittings, 2008). The group can be sampled using the same field collection technique and the total number of species employed is less than 1000. Two 
drawbacks are that moths are confined, in the main, to terrestrial habitats and, being mostly phytophagous, represent only one trophic level. But, another advantage is that they have recently been shown to be sensitive indicators of climate change in Ireland (O'Neill et al., 2012).

While typical flora has been well defined for active raised bog (Kelly \& Schouten, 2002), typical terrestrial invertebrate fauna, with the exception of spiders (Nolan, 2013), has not. The aim of this work was to establish whether there is a distinct moth fauna associated with the wettest areas of designated sites (active raised bog) by comparing the assemblages found in these study sites to those found on undesignated sites where this wet habitat has been lost (non-active raised bog). This work will inform site specific conservation objectives currently being developed for Raised Bog SACs in Ireland (DAHG, 2014). Moth species characteristic of higher quality raised bog habitat will be considered part of their typical fauna and included in conservation targets, where appropriate. This work can therefore be interpreted as boundary science, in the sense that it both advances scientific understanding and has implications for conservation managers and will be used to inform decision making (Cook et al., 2013).

\section{Materials and methods}

\section{Study sites}

Six designated and six undesignated bogs were selected for sampling. All sites were located wholly or in part in
County Offaly (Fig. 1) which, in the last all-Ireland assessment (Hammond, 1981), had the greatest amount of unmodified raised bog of the True Midland sub-type (7875 ha) of all counties. Clara Bog is the largest remaining example of this bog sub-type and the study area is centrally located within the range of such bogs (Cross, 1990). Also, three of the SAC study sites (Clara, Raheenmore and Mongan Bogs) are Statutory Nature Reserves, protected under Ministerial Order, and are the most intensively researched raised bogs in the country (Kelly \& Schouten, 2002; Fernandez et al., 2014). Restoration work, mainly in the form of extensive drain blocking, has taken place on Clara, Raheenmore, Sharavogue and Mongan Bogs (Kelly \& Schouten, 2002; Fernandez et al., 2014).

The designated raised bog sites selected constitute six out of the seven SAC bogs in County Offaly and contain varying amounts of active raised bog habitat ranging from 21 hectares (Moyclare) to 79 hectares (Clara west). Aerial photography interpretation was used to identify the nearest highly modified but vegetated, undesignated raised bog to each designated bog site (Fig. 1). The amount of active raised bog remaining on the highly modified undesignated bogs is not known but is considered to be very low, if any.

The area of raised bog on designated sites ranged from 74 hectares (Moyclare) to 246 hectares (Clara west) and on undesignated sites from 40 hectares (Kilballyskea) to 578 hectares (Clonaltra) (Appendix 2). Distance between protected sites ranged from $2 \mathrm{~km}$ (Ferbane to Moyclare) to $49.5 \mathrm{~km}$ (Sharavogue to Raheenmore). Distance between each designated site and its paired undesignated site ranged from $1.5 \mathrm{~km}$ (Raheenmore to Old Croghan) to

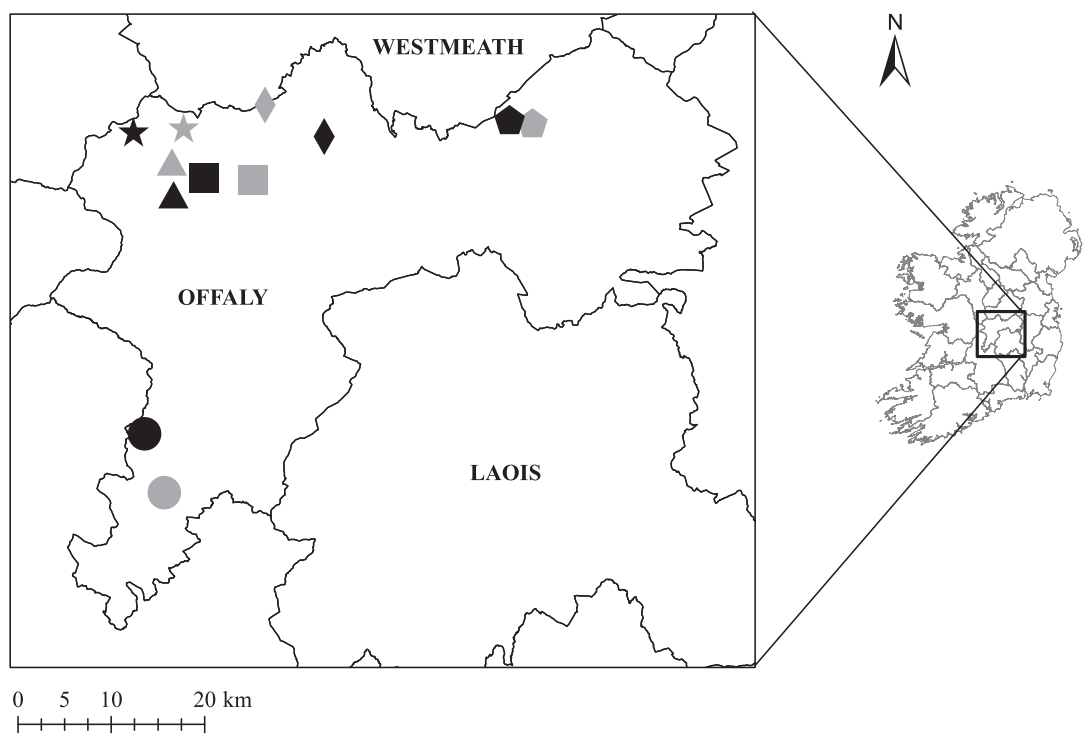

Fig. 1. Map of Co. Offaly, central Ireland showing location of study sites. Black symbols represent designated sites and grey symbols represent undesignated sites. Symbol shape represents how sites were paired: $\uparrow$ Mongan; $\downarrow$ Doon $\square$ Ferbane; Curraghalassa; Clara; Clonaltra; Moyclare; Clonlyon; Sharavogue; Kilballyskea; Raheenmore; Old Croghan. 
$5 \mathrm{~km}$ (Sharavogue to Kilballyskea). The average distance between designated and undesignated pairs was $3.5 \mathrm{~km} \pm$ 0.9 (mean $\pm \mathrm{SE}$ ).

Sampling on designated sites took place in the wettest, most pristine areas of active raised bog habitat. While on undesignated bogs, central locations on the degraded high bog remnants were selected as sampling points so that there was a maximum distance to the edge from the sampling point, thereby decreasing the number of vagrant species within the sampling range (Webb, 1989). Active raised bog habitat consists of both central and sub-central ecotopes, i.e. areas which have generally homogeneous biotic and abiotic conditions (sensu Kelly \& Schouten, 2002). Central ecotope has a very soft and often quaking surface and the microtopography usually ranges from pools to tall, well-developed hummocks, with pools usually frequent to dominant. Generally, sub-central ecotope is lawn-dominated with only a few hummocks. The surface is soft and sometimes quaking (Fernandez et al., 2005a). Flushes and soaks which have active Sphagnum growth are also classified as active raised bog (Fernandez et al., 2014). The largest area of central ecotope on each designated bog, as defined by Fernandez et al. (2005b,c), was selected as a sampling point. On Sharavogue bog, an area of sub-central ecotope was selected as this bog contains no central ecotope. On Ferbane Bog, placement of the trap within the central ecotope was not possible due to its extreme quaking nature. It was therefore placed in the marginal ecotope as close to central ecotope as possible. In marginal ecotope, the acrotelm is absent or poorly developed (Kelly \& Schouten, 2002). This ecotope is allocated to the degraded raised bog habitat type (Fernandez et al., 2005a).

\section{Sampling methodology}

Moths were sampled using portable light traps (Heathtype actinic $15 \mathrm{~W}$; Anglian Lepidopterist Supplies, Hindolveston, Norfolk, UK) (Heath, 1965). Twelve bogs were usually sampled over a two night period with six bogs sampled on each consecutive night (2nd/3rd July, 26th/ 27th July, 31th July/1st August, 24th/25th September and 1st/2nd October 2011). Therefore, six dyads (designated and undesignated bog pairs) were each sampled on five occasions, giving 30 dyad-sampling events (Fig. 1). Sampling dyads on the same night ensured that variation in abundances, caused by weather or natural light condition, did not affect within-pair comparisons. Between pair comparisons may still be affected by differences in other factors like trapping microsite and habitat-specific trapping bias. These limitations are discussed below. Nevertheless, on two occasions due to logistical issues, sites within a dyad had to be sampled one night apart, i.e. Ferbane, 26th July; Curraghalassa, 27th July; Mongan, 25th September; Doon, 24th September). Single species analyses were conducted excluding these samples and results were the same as if these samples were included. Multivariate analysis (ordination) was carried out excluding all sites on these sample dates and similar results were found to when they were included. But without these sample dates, the data set was weakly structured and more species had to be excluded to reach a useful ordination. Therefore, a decision was made to include these samples as the information they provided was considered to be greater than the potential noise they added to statistical analysis. Moth surveys were conducted when forecast weather conditions were suitable, i.e. minimum night temperature $>10^{\circ} \mathrm{C}$, maximum wind speed Beaufort 4-5; and with no persistent or heavy rain.

Trapping protocol and trap type were standardised whereby traps were deployed on the bogs before sunset and collected close to sunrise the following morning. Trapping was carried out with the assistance of three trained NPWS field staff, so that the timing of setting and collection of traps was closely aligned. Review of setting and collection times did not reveal any bias in favour of designated or undesignated sites. Traps were filled with nine standard-sized egg trays which were identically arranged in each trap to avoid noise. Traps were placed in the centre of a circle of plastic tubing, with an inner diameter of 1 metre. A timed 5-minute active search of the habitat and trap surface within the circle took place in the morning to reduce bias towards more conspicuous species. Traps and batteries were arbitrarily reassigned to sites each night to remove any bias of lamp brightness or battery strength. Trap openings were sealed and traps were placed in labelled, large black plastic sacks which were then sealed for transport to the laboratory for identification. Moths were identified to species level according to Skinner (2009) and Waring and Townsend (2009).

Four Amphipoea species occur in Ireland and can only be reliably distinguished by examination of genitalia where they occur together (Waring \& Townsend, 2009). All four species are considered bog associates and therefore were pooled as Amphipoea agg. and analysed with other such species. The species pair Mesapamea secalis (L.)/M. secalella (Remm), which also requires genitalia preparation to separate, was analysed as Mesapamea agg. Both species in this pair are considered bog associates, hence the species pair was interpreted as such.

\section{Environmental variables}

Environmental variables for each study site were derived from 2004/2005 series of aerial photographs for the sites and geospatial information processed in ArcGIS 10.2.1 (ESRI, 2008). In this study, environmental variables were calculated for Clara bog west only as this is where sampling took place. The following variables were calculated: (i) minimum distance from sampling point to bog edge, (ii) bog area, (iii) drain density (D) and (iv) connectivity (C).

Drain density (D) was calculated by dividing the total length of drains on the high bog by the area of the high bog. 
Connectivity (C) was expressed as the area of raised bog within a radius of $2 \mathrm{~km}$ of the sampling point, using a simple and commonly used proportional index (Winfree et al., 2005):

$$
C=\frac{A(r)}{\pi r^{2}}
$$

Where $A(r)$ is the total habitat area within radius $r$ of the sampling point. A $2 \mathrm{~km}$ radius was also used in a landscape scale heathland invertebrate study by Webb (1989) and is comparable with buffers used in more recent Lepidopteran studies: Slade et al. (2013) 1 km; FuentesMontemayor et al. (2012) 250-3000 m. It also encompasses the largest model predicted movement rate $\left(1707 \mathrm{~m} \mathrm{week}^{-1}\right)$ in a study of 87 common British nonmigratory species (Slade et al., 2013).

\section{Species variables}

Non-resident vagrants and atypical residents, whose presence was due to the invasion of raised bogs by noncharacteristic plant species, were separated from residents whose food plants form part of midland raised bog plant communities (Kelly \& Schouten, 2002; Fernandez et al., 2005a). Hereafter these are termed bog-associated species (Appendix 1). This was done using larval food plant and/ or habitat preferences in Emmet (1991), Bond and Gittings (2008) and Waring and Townsend (2009).

There has been no conservation assessment of moths in the Republic of Ireland to date. To assess conservation status of bog-associated moth species, any species classified as endangered or vulnerable by Conrad et al. (2006) for Great Britain were considered also to be of conservation concern in Ireland (Appendix 1). Species for which conservation status was not available were assigned a distribution status, based on the distribution maps and associated information in the Moths Ireland database (Tyner, 2014). Species assigned scarce (not encountered often or restricted in range) or rare (rarely encountered) status were considered vulnerable by virtue of their limited distribution. Distribution maps in Moths Ireland divide Ireland into $10-\mathrm{km}$ squares $(n=1019)$. Rare species in this study have been found in fewer than $3110-\mathrm{km}$ squares, whereas scarce species have been found in fewer than 130 10-km squares (Tyner, 2014). The database includes Northern Irish records.

\section{Statistical analyses}

The information-theoretic approach (e.g. Mazerolle, 2006) was used to compare two Poisson generalised linear models (GLMs) of the counts for the 14 species recorded in more than half of the 12 sites. The two models for each species were (i) site pair; and (ii) site pair and designation status. GLMs are mathematical extensions of linear models (McCullagh \& Nelder, 1989) and offer advantages in handling nonlinear ecological data relationships (e.g. Guisan et al., 2002; Marmion et al., 2009).

The modelling of the abundance data was undertaken in R (R Development Core Team, 2013). GLMs extend the linear modelling capability of $\mathrm{R}$ to scenarios that involve non-normal error distributions or heteroscedasticity. The Poisson distribution is widely used for the description of count data and is a one-parameter distribution, specified entirely by the mean (Agresti, 1996; Crawley, 2007). The mean-variance ratios range for the species data were close to 1 . Hence the Poisson GLM modelling assumptions were met. Here we applied two Poisson GLMs for each species; GLM1 modelled species counts as a function of site-pair, whereas GLM2 modelled counts as a function of both site-pair and designation status. This allowed us some measure of objective evaluation on the influence of designation status for each species using the information-theoretic approach that the Akaike information criterion (AIC) provides for the GLMs applied (e.g. Burnham \& Anderson, 2002). Of itself, the value of AIC for a given data set has no meaning. An AIC is most useful when compared to the AIC of other models for the same data, and the model with the lowest AIC should be favoured (e.g. Mazerolle, 2006). Hence, in our interpretation we favour the species models with the lower AIC values.

Rank-abundance diagrams (RADs) (MacArthur, 1957) were used to compare species richness, evenness and dominance in the moth communities on designated and undesignated sites. These diagrams provide an effective means of comparing community structure and may provide greater detail than a single diversity statistic (Krebs, 1999). To elucidate patterns of interest which may be obscured by aggregation of all species, an assemblage deconstruction approach (Matthews \& Whittaker, 2015) was used whereby a number of species subsets were separated from the complete assemblage.

Multi-response permutation procedure (MRPP) is a non-parametric procedure for testing the hypothesis of no difference between two or more groups (McCune \& Grace, 2002). MRPP is a multivariate analogue of an ANOVA and tests the within-group homogeneity by measuring a chance-corrected within-group agreement. A permutation procedure derives a simulated $P$ value to assess the effects of grouping variables on similarity among sites. The Sørensen statistic was used as the measure of ordination distance among moth assemblages because it is less influenced by absent species than other measures, which is good in sparse data sets such as this, where absence does not necessarily mean the habitat was unsuitable and the species was genuinely absent (Peck, 2010). This measure is also less sensitive to outliers, unlike other measures, in which large differences between samples are measured more heavily than several small differences (McCune \& Grace, 2002). MRPP was used to test difference among groups with designated site used as a grouping variable and using log-transformed abundance data for all species $(n=93)$, 
bog-associated species $(n=47)$ and bog-associated species of conservation concern $(n=15)$.

Indicator species analysis, using the method of Dufrêne and Legendre (1997), was carried out on groups defined by bog type, to assess group indicators based on species constancy and distribution of abundance.

Following investigation by graphing species as discrete variables using a Poisson distribution, the majority of species abundance responses were found to have strong skewness to the left. Therefore, statistical methods which assume normality had to be excluded. Non-metric multidimensional scaling analysis (NMS) is an ordination technique suited to non-normal data sets (McCune \& Grace, 2002). NMS was used to investigate patterns and differences in assemblage composition and also the relationship between assemblage composition and explanatory variables. Ordination was carried out on bog-associated species only. Other non-bog-associated species which may have been vagrants or originated within the raised bog study area due to the presence of invasive and non-typical species such as Pinus contorta (Douglas ex Loudon), P. sylvestris (L.), Salix and Betula species (Fernandez et al., 2014) or due to other habitats such as mineral rich soak systems and flushes being present, were considered to be a source of noise and were excluded. A similar exclusion was carried out by Oxbrough et al. (2012). Singletons were also excluded to reduce noise. This reduced the number of species from 47 to 37 . Due to the overriding influence of sample date, species presence-absence data were used. The Sørensen statistic was used as a distance measure. NMS was run in Autopilot mode five times using presence-absence data and a stress test was conducted at each iteration to determine dimensionality by graphing an NMS scree plot. All five scree plots suggested a three dimensional solution. MRPP, Indicator Species analysis and ordination were performed in PC-ORD (McCune \& Mefford, 2011).

\section{Results}

\section{Species data set}

A total of 1816 adult individuals of 93 moth species were recorded, representing $16 \%$ of the Irish macro-moth fauna (582 species) (Bond et al., 2006). A complete species list is given in Appendix 1. Of these, 47 species (1650 individuals) were classified as being associated with raised bog habitat. Although this number of species is somewhat small, the species accumulation curves for designated and undesignated sites approach an asymptote (Fig. 2). Ten families were recorded, with two families (Noctuidae and Geometridae) together accounting for $90 \%$ of individuals. Four species dominated the data set: Lycophotia porphyrea (D. \& S.), Apamea monoglypha (Hufn.), Noctua pronuba (L.) and Dyscia fagaria (Thunb.). Lycophotia porphyria was the most abundant species on all sites representing just over $50 \%$ of individuals $(n=947)$. Many

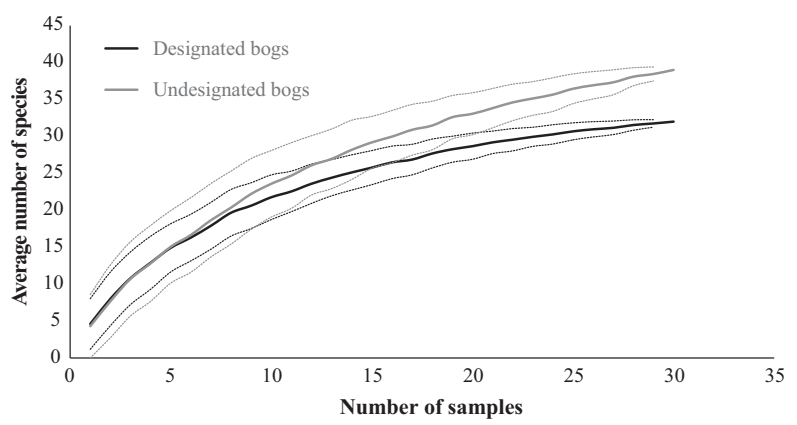

Fig. 2. Species accumulation curves. For designated sites, based on the occurrence of 32 bog-associated species in 30 subsamples. For undesignated sites, based on the occurrence of 39 species in 30 subsamples. Average species richness was based on randomisation procedure outlined in McCune and Grace (2002). Hatched lines represent \pm 1 standard deviation from the mean.

species were rare, with $47 \%$, or 44 of the 93 moth species, represented by only one or two individuals.

On designated bogs $(n=6)$, a total of 951 individuals of 67 species were identified. A similar result was obtained from undesignated bogs $(n=6)$, where a total of 865 individuals of 73 species were recorded. On designated sites, 33 species (883 individuals) and on undesignated sites, 39 species (767 individuals) were associated with raised bogs. For designated sites, the species-accumulation curve appeared to approach asymptote more rapidly, at a lower value of species richness (Fig. 2), indicating that there are generally fewer bog-associated species at the designated sites. But, for most of the curve, difference between bog types is only marginally significant due to the overlapping standard deviations but the curves begin to diverge as samples accumulate and standard deviations cease to overlap so that this pattern becomes more apparent.

\section{Common species: individual species analyses}

We used the strengths of the information-theoretic approach to objectively evaluate the information provided when site designation status is included as a factor in our count GLMs versus when it is excluded (Table 1). Neither model had the support of all species. Still, site and designation (GLM2, model 2) were a better explanation of abundance than site pair alone (GLM1, model 1) for six of the fourteen species (positive delta AIC values $>2.0$ ). The negative delta AIC measures between GLM1 and GLM2 for seven species were all less than 2 - commonly taken to indicate little evidence of difference in model quality. Therefore, model 2 was supported over model 1 in six cases - but in no cases was there strong evidence supporting model 1 over model 2 perhaps due to the dissimilarity in species abundance between site pairs. Of the six species where site and designation status are a better explanation of abundance, A. monoglypha, N. pronuba and Dicallomera fascelina (L.) were more abundant on designated sites, whereas 
Table 1. Summary of Akaike information criterion (AIC) for the Poisson generalised linear models (GLMs) on the species count data comparing site-pair only and site pair and designation status as factors for the most common fourteen species found on more than half the sites.

\begin{tabular}{lrrr}
\hline & \multicolumn{3}{c}{ AIC } \\
Species & AIC GLM1 & GLM2 & $\Delta$ AIC \\
\hline Apamea monoglypha (Hufn.) & 174.68 & 155.17 & 19.51 \\
Pharmacis fusconebulosa (DeG.) & 51.41 & 44.68 & 6.73 \\
Noctua pronuba (L.) & 85.82 & 80.66 & 5.16 \\
Eupithecia nanata (Hb.) & 49.87 & 45.08 & 4.79 \\
Thera britannica (Turner) & 34.12 & 29.38 & 4.74 \\
Dicallomera fascelina (L.) & 51.04 & 48.42 & 2.62 \\
Lycophotia porphyrea (D.\& S.) & 303.21 & 302.24 & 0.97 \\
Arctia caja (L.) & 43.10 & 43.44 & -0.34 \\
Dyscia fagaria (Thunb.) & 88.12 & 88.87 & -0.75 \\
Eilema lurideola (Zin.) & 66.18 & 67.82 & -1.64 \\
Selidosema brunnearia (Vill.) & 73.71 & 75.58 & -1.87 \\
Agrotis exclamationis (L.) & 28.56 & 30.45 & -1.89 \\
Mesapamea secalis agg. & 29.94 & 31.83 & -1.89 \\
Laothoe populi (L.) & 35.35 & 37.27 & -1.92 \\
\hline
\end{tabular}

GLM 1 = site pair only; GLM 2 = site pair \& designation status.

Pharmacis fusconebulosa (DeG.), Eupithecia nanata (Hb.) and Thera britannica (Turner) were more abundant on undesignated sites. These six species show evidence (delta AIC >2) of designation status affecting their abundance, whereas the remaining species show little evidence (delta AIC $<2$ ) of such an effect. Sizes (difference in mean counts, taken from fitted models, between designated and undesignated sites), and evidence strength (based on delta AIC values) for the six species with evidence of an effect of designation status are shown in Tables 1 and 2.

\section{Rank-abundance diagrams}

Rank-abundance diagrams of designated and undesignated bogs showed similar species richness, evenness and dominance patterns for all species and also when deconstructed to show species of conservation concern and bogassociated species only (Fig. 3a-c). Interestingly, RADs for bog-associated species of conservation concern (Fig. 3d) showed that 11 out of 15 bog-associated species of conservation concern were, paradoxically, more abundant on undesignated sites. This could be because areas of undesignated bogs sampled were, in general, drier than sampled areas of designated sites. Further sampling is needed on drier areas of designated sites to elucidate if they are really depauperate in terms of these species abundances. Three high rank bog-associated species of conservation concern, namely $D$. fascelina, Selidosema brunnearia (Vill.) and Arctia caja (L.), were more abundant on designated sites. In other words, on designated sites, there is a group of three bog-associated species of conservation concern that are more abundant, by approxi- mately an order of magnitude or more, than other such species. Meanwhile, on undesignated sites, bog-associated species of conservation concern show a more gradual decline in abundance with decreasing abundance rank. In terms of diagram shapes, the designated sites appear to show a broken stick shape, whereas the undesignated sites appear to show a log normal shape (Magurran, 2004).

\section{Multi-response permutation procedure (MRPP)}

Similar to the RADs, the difference between groups as defined by designation status was not significant for either all species $(n=93)$ or bog-associated species $(n=47)$. Yet, a significant difference between bog types was detected when tested using bog-associated species of conservation concern $(n=15)$. Chance-corrected within-group agreement, $A$ was 0.046 , Test statistic (T) was -1.900 and $P=0.0418$. While the within-group agreement $A$ was low, the difference between observed and expected delta was significant. Therefore, groups were significantly different from each other even though within-group homogeneity was low. Indicator species analysis was carried out on these groups (log-transformed abundance data, $4999=$ number of randomisation runs) and D. fascelina was found to be a significant indicator of designated sites $(P=0.0526)$.

\section{Non-metric multidimensional scaling (NMS) ordination}

Non-metric multidimensional scaling ordination (Figs 4 and 5) explained a cumulative $86 \%\left(r^{2}=0.863\right)$ of the variation in the moth species presence-absence data, with three major gradients capturing most of the variance in the communities; Axis 1 accounting for $42.7 \%$ $\left(r^{2}=0.427\right)$ and Axis 2, 24.3\% $\left(r^{2}=0.243\right)$ and Axis 3, $19.3 \%\left(r^{2}=0.193\right)$. The designated and undesignated bogs did not cluster together, but rather formed a continuum, mainly from undesignated to designated bogs from the positive to the negative side of Axis 2. But, Old Croghan and Kilballyskea, both undesignated bogs, seem more aligned with the designated bogs on this axis, whereas Ferbane appears to align with the undesignated bogs as an outlier from the rest of the designated bogs (Fig. 4a). In general, the designated sites were less variable than the undesignated sites. Two undesignated sites (Clonaltra and Kilballyskea), were strong outliers from the rest of the bogs on the negative side of Axis 1 .

Of the four explanatory variables investigated (Appendix 2), only two showed a correlation $\left(r^{2}\right.$ value $\left.=0.299\right)$ with Axis 1 or 2 . The negative side of Axis 1 correlated with drain density, whereas the negative side of Axis 2 correlated with distance of the trapping site from the edge of the bog (Fig. 4a).

On Axis 1 the six species which had the greatest positive influence were Eilema lurideola (Zin.), A. caja, Mythimna impura (Hb.), D. fagaria, Cleorodes lichenaria (Hufn.) and Euthrix potatoria (L.) (Table 3, Fig. 4b). The 
Table 2. Predicted mean counts from fitted Poisson generalised linear models (GLMs) for each site pair by species.

\begin{tabular}{|c|c|c|c|c|c|c|c|c|}
\hline Site & Species & Site pair & $\begin{array}{l}\text { Site pair \& } \\
\text { designation }\end{array}$ & Site count & Species & Site Pair & Site pair \& designation & Site count \\
\hline Sharavogue & \multirow{12}{*}{ APAMMONO } & 20.25 & 26.45 & 5 & \multirow{12}{*}{ EUPINANA } & 1.69 & 0.71 & 1 \\
\hline Kilballyskea & & 20.25 & 14.04 & 2 & & 1.69 & 2.67 & 2 \\
\hline Mongan & & 19.62 & 25.64 & 37 & & 1.65 & 0.69 & 1 \\
\hline Doon & & 19.62 & 13.60 & 27 & & 1.65 & 2.60 & 0 \\
\hline Ferbane & & 19.02 & 24.85 & 33 & & 1.60 & 0.67 & 8 \\
\hline Curraghalassa & & 19.02 & 13.19 & 16 & & 1.60 & 2.53 & 0 \\
\hline Moyclare & & 18.43 & 24.09 & 44 & & 1.56 & 0.66 & 1 \\
\hline Clonlyon & & 18.43 & 12.78 & 19 & & 1.56 & 2.46 & 0 \\
\hline Clara west & & 17.87 & 23.34 & 9 & & 1.52 & 0.64 & 2 \\
\hline Clonaltra & & 17.87 & 12.39 & 10 & & 1.52 & 2.40 & 1 \\
\hline Raheenmore & & 17.32 & 22.63 & 19 & & 1.48 & 0.62 & 2 \\
\hline Old Croghan & & 17.32 & 12.01 & 4 & & 1.48 & 2.33 & 1 \\
\hline Sharavogue & \multirow[t]{12}{*}{ PHARFUSC } & 1.29 & 0.43 & 0 & \multirow[t]{12}{*}{ THERBRIT } & 3.82 & 1.43 & 1 \\
\hline Kilballyskea & & 1.29 & 2.16 & 4 & & 3.82 & 6.22 & 6 \\
\hline Mongan & & 1.37 & 0.46 & 0 & & 2.04 & 0.76 & 1 \\
\hline Doon & & 1.37 & 2.28 & 1 & & 2.04 & 3.31 & 4 \\
\hline Ferbane & & 1.45 & 0.48 & 1 & & 1.09 & 0.41 & 1 \\
\hline Curraghalassa & & 1.45 & 2.42 & 2 & & 1.09 & 1.76 & 2 \\
\hline Moyclare & & 1.54 & 0.51 & 0 & & 0.58 & 0.22 & 0 \\
\hline Clonlyon & & 1.54 & 2.56 & 0 & & 0.58 & 0.94 & 0 \\
\hline Clara west & & 1.63 & 0.54 & 2 & & 0.31 & 0.12 & 0 \\
\hline Clonaltra & & 1.63 & 2.71 & 7 & & 0.31 & 0.50 & 0 \\
\hline Raheenmore & & 1.72 & 0.57 & 0 & & 0.16 & 0.06 & 0 \\
\hline Old Croghan & & 1.72 & 2.87 & 1 & & 0.16 & 0.27 & 1 \\
\hline Sharavogue & \multirow[t]{12}{*}{ NOCTPRON } & 9.88 & 12.47 & 5 & \multirow[t]{12}{*}{ DICAFASC } & 2.21 & 3.12 & 4 \\
\hline Kilballyskea & & 9.88 & 7.29 & 1 & & 2.21 & 1.31 & 1 \\
\hline Mongan & & 9.32 & 11.77 & 18 & & 2.23 & 3.14 & 4 \\
\hline Doon & & 9.32 & 6.88 & 10 & & 2.23 & 1.32 & 0 \\
\hline Ferbane & & 8.79 & 11.10 & 17 & & 2.24 & 3.16 & 3 \\
\hline Curraghalassa & & 8.79 & 6.49 & 9 & & 2.24 & 1.33 & 1 \\
\hline Moyclare & & 8.30 & 10.47 & 14 & & 2.26 & 3.18 & 2 \\
\hline Clonlyon & & 8.30 & 6.12 & 8 & & 2.26 & 1.34 & 0 \\
\hline Clara west & & 7.82 & 9.88 & 7 & & 2.27 & 3.20 & 5 \\
\hline Clonaltra & & 7.82 & 5.77 & 4 & & 2.27 & 1.35 & 5 \\
\hline Raheenmore & & 7.38 & 9.32 & 4 & & 2.29 & 3.22 & 1 \\
\hline Old Croghan & & 7.38 & 15.45 & 6 & & 2.29 & 1.35 & 1 \\
\hline
\end{tabular}

Site pair and site pair and designation provide the mean predicted counts from GLM1 and GLM2 respectively; Site count provides the recorded species abundances for comparison. Moth species have been nominated using an abbreviated form of their name. This is formed by taking the first four letters of the genus and the species names and putting them together. In Appendix 1 a list of these abbreviated forms may be found beside the full name and authority, family and conservation status.

species with the greatest negative influence on Axis 1 scores were Alcis repandata (L.), Phlogophora meticulosa (L.) and Noctua comes (Hb.). Four species had a positive influence on Axis 2: Syngrapha interrogationis (L.), Idaea aversata (L.), E. nanata and E. glareosa. The three species with the greatest negative influence on Axis 2 scores were: S. brunnearia, Macrothylacia rubi (L.) and A. menyanthidis. This side of Axis 2 is associated with designated raised bogs and, therefore, these species are of interest as potential indicators. Of the sixteen species above, just four were found on only two sites; A. menyanthidis was present at Mongan (2) and Clara (1), E. glareosa was found at Clonaltra (1) and Curraghalassa (3), C. lichenaria was found on Moyclare (1) and Doon (1) and E. potatoria was found on Moyclare (1) and Clonlyon (1) (abundance in brackets).
For clarity, bog-associated species of conservation concern were also plotted separately (Fig. 4c).

\section{Discussion}

This study is the first to evaluate whether there is a distinct moth fauna associated with active raised bog habitat on designated sites by comparing them to undesignated sites where this habitat has been lost. The study did reveal differences between the faunas of each site type which are discussed below. But, one of the most interesting results, revealed by RADs, was that several bog-associated species of conservation concern were more abundant on undesignated sites. This result should not be interpreted as 


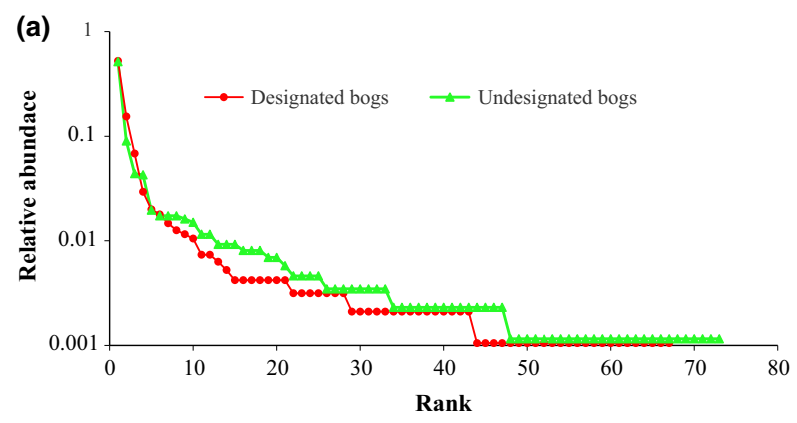

(b)
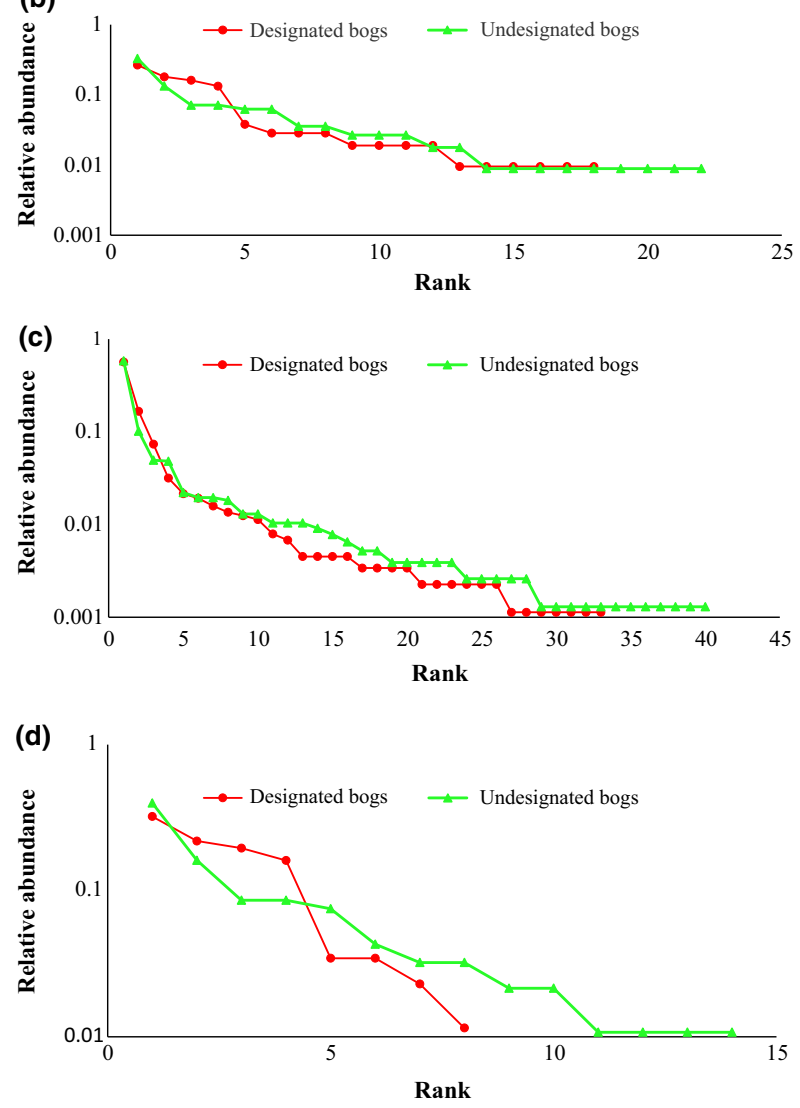

Fig. 3. Rank-abundance diagrams. The y axis shows the relative abundance of species (plotted using a $\log 10$ scale), whereas the $x$ axis ranks each species in order from most to least abundant. (a) all species; (b) species of conservation concern; (c) bog-associated species; (d) bog-associated species of conservation concern.

indicating that undesignated, degraded sites hold similar or greater species richness of bog associates than designated sites. As found in previous raised bog studies (Väisänen, 1992; Bezděk et al., 2006) many characteristic Lepidoptera, even species of conservation concern, may have a preference for such drier areas than central active raised bog habitat. More detailed survey work on designated sites including drier marginal habitat as well as wet active raised bog habitat is required to determine this. We suspect, given the species and their biologies, designated sites would perform better than undesignated sites in terms of characteristic biodiversity maintenance under such a sampling regime. But, the contrary cannot be ruled out which would cast doubt on the efficacy of the coarse filter conservation approach for Lepidoptera. Ferbane Bog, where sampling took place in a dry marginal area, was the most species-rich of all designated sites but still had fewer bog-associated species than the two most speciose undesignated sites and Van Duinen (2013) found that the number of characteristic macroinvertebrates is not clearly related to the presence of a characteristic raised bog vegetation.

Designations should be reviewed as more species data become available to determine sites' biodiversity maintenance function. Poorly performing designated sites should be prioritised for restoration management, or where evidence points to undesignated bogs performing strongly, such sites should be considered for conservation. For example ordination shows that Old Croghan aligns more with designated sites, and if added to the suite of designated sites would presently increase the representation of bog associates by four additional species. This highlights the possible role undesignated botanically degraded raised bogs may have to play in bog-associated invertebrate conservation.

The single species analysis revealed that $A$. monoglypha, $N$. pronuba and $D$. fascelina were more associated with designated than undesignated sites. Both A. monoglypha and $N$. pronuba are very common and widespread species (Waring \& Townsend, 2009) but have been previously recorded from central areas of an Irish raised bog (Bond, 1989) and are considered bog-associated species in this study. A possible explanation for the alignment is greater species abundance in the landscape surrounding such sites due to less intensive agricultural management. Both species are highly mobile (Slade et al., 2013) and are likely vagrants onto raised bogs. But, paired designated and undesignated sites lie within the same landscape matrix under the same general management, with much improved agricultural grassland, other bog fragments and some conifer plantation and scrub.

As with larval stages, adult moths also have specific nectar host plants which may explain the preference of these nectar-feeding species for designated raised bogs. Using data from a long-term German study, Altermatt and Pearse (2011) recorded a number of adult host plants for both species (A. monoglypha; 4 taxa and $N$. pronuba; 13 taxa). These two species were found to be among the 25 most important pollen vectors out of a sample of 103 nocturnal moth species in a study of Scottish pine forest (Dévoto et al., 2011). Interactions with plants were observed indirectly through sampling pollen load, which was found to be from the pooled taxa Erica cinerea/tetralix. Pine forest understory contains a number of the woody ericoid scrubs, including $C$. vulgaris but E. cinerea/ tetralix was found to be the sole structurally important taxon for all visiting moth species.

While E. cinerea is absent from Irish midland raised bogs, E. tetralix is commonly found (Kelly \& Schouten, 

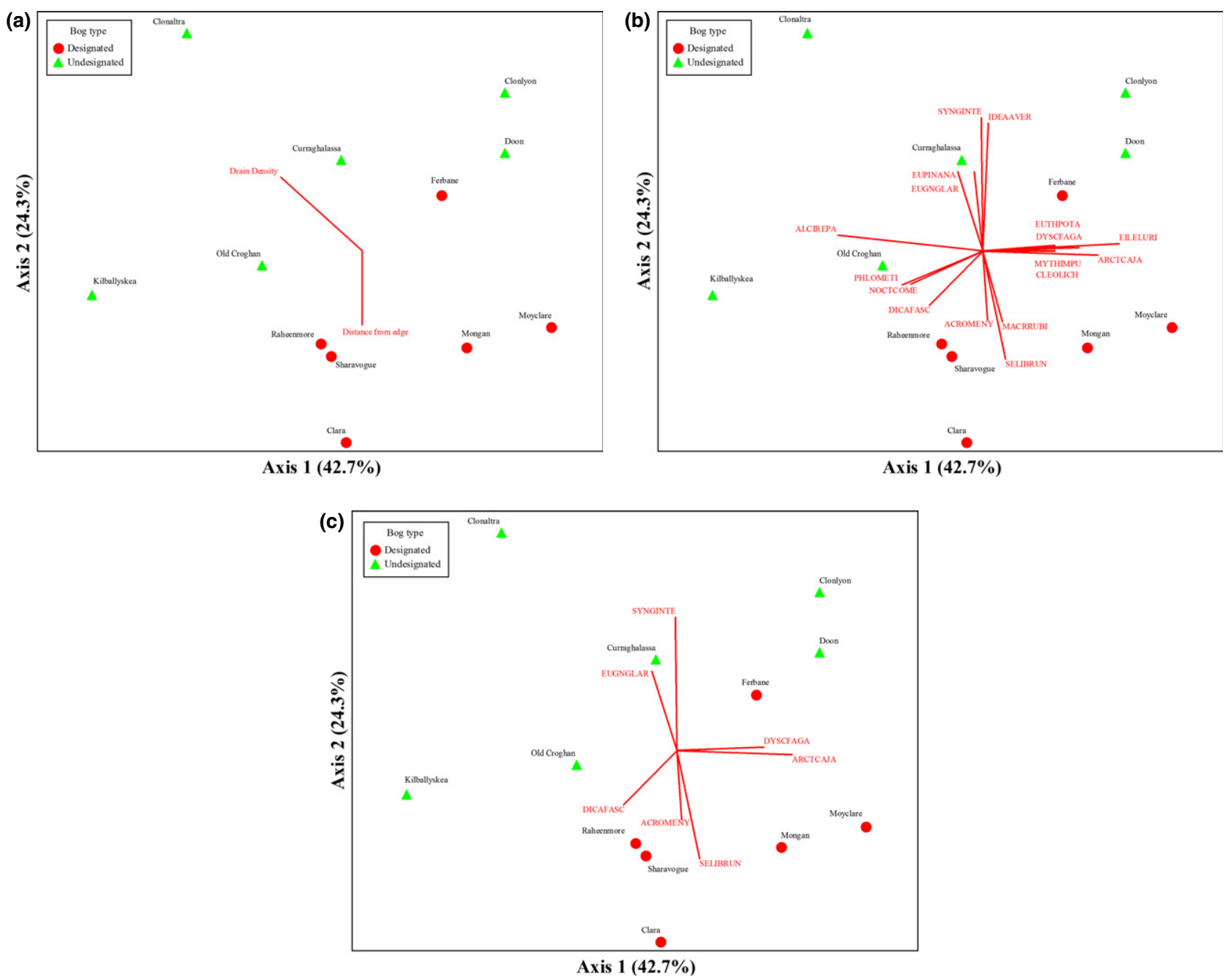

Fig. 4. Non-metric multidimensional scaling (NMS) ordination of bog-associated moth assemblages at 12 sample sites. Joint plots with vectors depicting (a) environmental variables, (b) bog-associated species and (c) bog-associated species of conservation concern; joint plot cut-off value $r^{2}=0.299$ where $r^{2}$ is relative to the combination of axis 1 and 2 correlation coefficients; the amount of variation explained by each axis is included in parentheses; final stress $=6.194$; final instability $=0$.

2002) and grows well on hummocks within central ecotope (Kelly et al., 1995). This species is associated with waterlogged soil conditions (Jones \& Etherington, 1970) and is widespread but found at low abundance on degraded, cutover bogs (M. McCorry, pers. comm.). It is possible that the alignment of $N$. pronuba and $A$. monoglypha with designated sites is due to the greater abundance of one of their preferred nectar sources, E. tetralix. Due to their mobility, it is likely that vagrants from the surrounding landscape do enter designated sites but presence may be due to the greater nectar availability rather than greater abundance in the landscape. Furthermore, evidence suggests a correlation between oviposition sites and nectar-producing flowers (Altermatt \& Pearse, 2011) which may increase resident populations of these species on designated sites.

Dicallomera fascelina is considered a rare peatland species in Ireland where the majority of records are from midland raised bogs (Tyner, 2014) and therefore its alignment with designated sites is of interest. Its larval food plant is C. vulgaris, which is widespread on peatland and so its rarity may be related to other habitat or microhabitat features not found on undesignated degraded sites. This would merit further study.

Host larval food plant provides an explanation for the alignment of $P$. fusconebulosa, E. nanata and T. britannica with undesignated sites. Pharmacis fusconebulosa feeds on the roots of bracken, but it has been found on the roots of red fescue and probably also uses the roots of broadleaved herbs (Waring \& Townsend, 2009). Neither of the known food plants occur on good quality raised bog. The larval stages of E. nanata feed on the flowers of $C$. vulgaris (Waring \& Townsend, 2009). This plant has been noted to flower abundantly under conditions of greater soil aeration in degraded bog areas (Kelly \& Schouten, 
Table 3. Species variables correlation with non-metric multidimensional scaling ordination axes.

\begin{tabular}{lll}
\hline Variables & $r$ & $r^{2}$ \\
\hline Axis & 1 & \\
Eilema lurideola (Zin.) & 0.771 & 0.595 \\
Arctia caja (L.) & 0.708 & 0.502 \\
Mythimna impura (Hb.) & 0.647 & 0.419 \\
Dyscia fagaria (Thun.) & 0.615 & 0.378 \\
Cleorodes lichenaria (Hufn.) & 0.559 & 0.313 \\
Euthrix potatoria (L.) & 0.559 & 0.312 \\
Alcis repandata (L.) & -0.793 & 0.629 \\
Phlogophora meticulosa (L.) & -0.592 & 0.350 \\
Noctua comes (Hb.) & -0.561 & 0.314 \\
Axis & 2 & \\
Syngrapha interrogationis (L.) & 0.762 & 0.580 \\
Idaea aversata (L.) & 0.746 & 0.556 \\
Eupithecia nanata (Prout) & 0.588 & 0.346 \\
Eugnorisma glareosa (Esp.) & 0.586 & 0.343 \\
Selidosema brunnearia (Vill.) & -0.686 & 0.470 \\
Macrothylacia rubi (L.) & -0.555 & 0.308 \\
Acronicta menyanthidis (Esp.) & -0.547 & 0.299 \\
Dicallomera fascelina (L.) & -0.485 & 0.235 \\
\hline
\end{tabular}

2002) and provides an explanation for the alignment of this species with degraded sites. Thera britannica feeds on coniferous trees which are considered invasive species on raised bogs (Fernandez et al., 2014) and are more abundant on drier undesignated sites.

Rank abundance diagrams of the communities in this study showed generally no difference between degraded and protected raised bogs. But, the diagram for 'bog-associated species of conservation concern' was different with a greater evenness of high relative abundance species on protected compared to degraded sites. Visual inspection of the graph of bog-associated species of conservation concern (Fig. 3d) suggests that designated bogs show a Broken Stick distribution (MacArthur, 1957), which has been described as a more equitable distribution than the Log Normal distribution (Fattorini, 2005) and has good fits for communities with relatively high evenness between species (Giller, 1984). This finding has important conservation implications as it shows that designated sites may be more resilient than undesignated sites and thereby better able to conserve species of conservation concern associated with raised bog habitat. This also indicates that for this specific sub-set of species bog designation appears to be fulfilling its promise in the 'coarse filter' approach.

Ordination revealed that designated sites were less variable than undesignated sites in terms of assemblage composition, probably due to the similarity of the sampled habitat. Two undesignated sites (Clonaltra and Kilballyskea) were strong outliers from the rest. Clonaltra is a secondary degraded raised bog and has been highly modified. Kilballyskea is an intact degraded site but has been extensively drained and is covered with tall $(>1 \mathrm{~m})$, rank heather and invasive Pinus species. Neither bog area nor connectivity was found to be significantly related to change in assemblage composition across sites as revealed by ordination. Although this is contrary to the expectations of the theory of island biogeography (MacArthur \& Wilson, 1967), Savage et al. (2011) also found that bog size had no influence on species richness or diversity in a study of Nearctic bog dipteran fauna. It should, however, be noted that sample size was fairly low $(6+6)$ to test the theory of island biogeography.

Ordination also showed that the directional shift in assemblage composition associated with designation status was related (Pearson's $r=-0.566$ ) to distance from the edge of the bog. Slade et al. (2013) found that 'distance to the edge' was the most important predictor of the abundance of moth species with a strong forest affinity, suggesting that species found to be associated with designated bogs are bog specialists. Acronicta menyanthidis, $M$. rubi and S. brunnearia were correlated with designated raised bogs indicating that these species could be associated with active raised bog habitat. Acronicta menyanthidis is considered a stenotopic species obligatorily associated with or restricted to peat bogs in Europe (Spitzer \& Danks, 2006). One of its larval foodplants is Menyanthes trifoliata, a common species of bog pools, the presence of which indicates very wet conditions (Kelly \& Schouten, 2002). This species was only found on Mongan and Clara Bogs, which have the largest amount of central ecotope in this study.

Macrothylacia rubi is a widespread species which overwinters as a larva on or just beneath the ground under moss or leaf litter (Waring \& Townsend, 2009) and links to designated sites may be due to the availability of overwintering habitat.

Selidosema brunnearia is scarce species with a complex distribution (Skinner, 2009). In Europe, it is found on dry Calluna heathland on sandy soil, dry limestone steppes in the south of its range and also on wet acid bogs, mostly in Ireland and Scotland (Gelbrecht et al., 1997; Waring \& Townsend, 2009). On wet raised bogs in the Irish midlands, it may be that it uses moss hummocks which provide microhabitat conditions such as a dry environment (similar to its heathland and steppe habitat) and a specific thermal range, allowing larvae to burrow into the hummock during cold spells. For example on bogs in Russia, Mazei and Tsyganov (2007) found a xerophilous testate amoebae community on Sphagnum hummocks. On raised bogs in Ireland, water table levels stay below hummock surface level all year with the lowest water table levels experienced by hummocks comprised of Sphagnum austinii (Kelly \& Schouten, 2002). Cover of C. vulgaris, its food plant, is frequently high on this and certain other hummock types (Kelly \& Schouten, 2002). The reason for the restricted distribution of $S$. brunnearia merits further study, as it shows potential as an active raised bog indicator species and in addition appears to be endangered over some of its range (Gelbrecht et al., 1997).

The species associated with the positive end of Axis 2 (S. interrogationis, I. aversata, E. nanata and E. glareosa), along with species aligned with undesignated bogs in sin- 
gle species analysis, may have potential to be used as 'negative indicators' of degraded raised bog. S. interrogationis feeds on heather and has been found to be associated with peat bog margin in central Europe, which agrees with our finding (Bezděk et al., 2006). Singletons of this species were found on three undesignated sites (Clonaltra, Curraghalassa and Clonlyon Glebe). Bond and Gittings (2008) also mention that it comes singly to light traps and also note that it is probably in decline in much of the Irish midlands. Eugnorisma glareosa feeds on heather, among other plants, and is associated with dry heath, a habitat more akin to degraded than wet, active raised bog. This species had declined by $90 \%$ between 1968 and 2002 (Waring \& Townsend, 2009). Idaea aversata is a widespread species. Its food plants include Galium species (Waring \& Townsend, 2009). Galium saxitale is associated with cutover bog plant communities which explains I. aversata's orientation to undesignated sites (Kelly \& Schouten, 2002).

Single species analysis and multivariate analysis revealed different species aligned with designated sites. An explanation for this may be that the former analysis used abundance data, whereas multivariate analysis used presence-absence data. The two analyses may complement each other.

\section{Limitations}

Trapping effects. The main limitation of this study are the numerous biases inherent in the use of light traps (Dévoto et al., 2011) due to the varying responses of moths to light determined by their behaviour and physiology. For example body size, flight ability, sex, host plant specificity, flight season, weather conditions (particularly temperature) and moon phase can all influence trapping rates (Beck \& Linsenmair, 2006; Betzholtz \& Franzén, 2011; Jonason et al., 2014).

Due to the above sources of bias, light trapping is a sampling method which gives a measure of mobility and attraction to light rather than of relative or absolute abundance. The trapping protocol was standardised as far as possible so that bias remained constant. Although, even when an attempt to trap on consecutive nights with similar weather conditions was made, differences in moth activity between nights may have masked underlying true abundance differences. Ordination analysis was therefore based on presence-absence rather than abundance counts to overcome this weakness. It is recommended that in future, sampling is exactly temporally aligned. By exploiting the higher moth activity during warm nights and having an understanding of the species' phenology, it is possible to increase the number of species caught and reduce effects of confounding abiotic factors (Jonason et al., 2014). Alternatively, a range of abiotic factors, such as temperature, rainfall, wind speed, moonlight, and cloud cover should be recorded at trap events and used to correct for their effects on moth flight activity and trap effi- ciency during data analysis (Beck et al., 2011). Our study design meant that designated and undesignated group analyses were less affected by bias than individual site by site analysis.

Differences in species' behaviour between designated and undesignated sites may also have led to bias. For example particular species might tend to make longer distance movements in sub-optimal habitats, due to scarcity of food plants or mates, thereby increasing the likelihood of capture. But, routine explorative (e.g. foraging) behaviour results in slower, looping flights and occurs within smaller spatial scales (Van Dyck \& Baguette, 2005) and so such individuals may be less likely to end up in traps than migrating or dispersing species, associated with high population density and strong directional flight (Van Dyck \& Baguette, 2005; Betzholtz \& Franzén, 2013).

Our study assumes that sampling efficiency was equivalent among sites, particularly between designated and undesignated sites. Denser vegetation, for example invasive trees and scrub on undesignated sites, can reduce visibility of traps and hence their attraction radius resulting in a smaller sample of individuals and lower apparent species richness. Traps were placed in habitat which had good visibility for at least $20-30 \mathrm{~m}$. The radius of attraction for moths, of low powered light traps, similar to those used in this study, has been found to be very small, often even below $10 \mathrm{~m}$ (Truxa \& Fiedler, 2012) and so the issue of vegetation density reducing trap visibility is not considered to be significant, except in the case of Kilballyskea where visibility is likely to have been reduced due to uniform tall $>1 \mathrm{~m}$ heather growth. Even though sampling on Ferbane took place in marginal ecotope as close to central ecotope as possible, this bog aligned with undesignated sites in ordination analysis suggesting that light trapping can have a very limited attraction range.

Even though light trapping is the most effective technique for general moth recording (in terms of the wide spectrum of species it attracts relative to the sampling effort [Waring \& Townsend, 2009]), many moth species (day-flying species in particular) are rarely, if ever, attracted to light. Such bog-associated species may include Anarta myrtilli (L.), Ematurga atomaria (L.), Idaea muricata (Hufn.), Rheumaptera hastana (L.), Orgyia antiqua (L.), Phytometra viridaria (Clerck), Chiasmia clathrata (L.), Eupithecia satyrata (Hub.), Parasemia plantaginis (L.) and Diacrisia sannio (L.) (Bond, 1989; Waring \& Townsend, 2009). None of these species, with the exception of E. atomaria are known to be notably abundant on Irish raised bogs (Bond, 1989), with many considered scarce or rare (Tyner, 2014). While we consider our sampling method to have detected relative patterns of species richness/abundance between designated and undesignated sites, it has not fully described the moth fauna of these sites. Netting is considered the most appropriate sampling method for day-flying moths and a comparative study to ours using this method would be worthwhile, to see whether similar patterns emerged using a different suite of species and sampling method. Netting may be more effec- 
tive in sampling certain bog-associated dusk flying species such as Hypenodes humidalis (Waring \& Townsend, 2009) and Carsia sororiata, the latter a bog specialist (Spitzer \& Danks, 2006), not recorded on Irish raised bogs in recent years (Tyner, 2014), as well as micromoths, which can be underrepresented at light traps (Fuentes-Montemayor et al., 2012).

Flight season and optimal sampling regime. Sample size was relatively low $(6+6$ sites $)$ and sites were confined to one county. But, sampled bogs are all of the True Midland sub-type, which occur under similar climatic conditions (Cross, 1990; van der Schaaf, 2002) and lie centrally within the range of such bogs. In addition, sampling on designated sites was (apart from on one site) conducted in areas defined as active raised bog habitat using a nationally standardised methodology (Fernandez et al., 2014) and so the designated bogs sampled are considered representative of this habitat type within this bog sub-type.

When light sampling duration is limited ( $<10$ nights), as in this study, it has been shown to be slightly better to concentrate on the warmest summer nights (June August) (Jonason et al., 2014). Sampling in this study commenced at the beginning of July, however, preliminary light trapping in mid and late June 2009/2010 on six SAC raised bogs recorded 26 June flying bog-associated species, 20 of which were recorded in July 2011 (Flynn, 2014). The six species missing in 2011 were recorded at low abundance $(<8$ specimens in 2 years) so the impact of their absence is not considered significant. Review of 3 years of sampling data revealed that phenological factors, including perhaps adaptations to nectar availability, seem to have a strong effect on patterns of moth species richness and abundance, which is similar to the finding of Jonason et al. (2014). In 2011, when trapping focused particularly at the end of July and beginning of August, a number of bog-associated moth species were found in significantly greater abundance than in the previous 2 years preliminary sampling (e.g. A. monoglypha; 2009/2010 =38, $2011=225)$, L. porphyrea; $2009 / 2010=162,2011=947)$, N. pronuba; $2009 / 2010=44,2011=103$ ) and $S$. brunnearia $2009 / 2010=1,2011=32$ ). Selidosema brunnearia is of interest as abundance increased from 1 to 32 , indicating that this species has a particularly short flight season, which was adequately covered in 2011, but not in the previous 2 years. A remarkably short flight season (4-24/8) was noted by Gelbrecht et al. (1997) for this species. Saturnia pavonia, a bog-associated species with a flight period April/ May was not sampled in 2011. Macrothylacia rubi and Ceramica pisi (max flight season in early June) were underrecorded. As for Autumn/Winter flying species, the maximum flight season of Xestia agathina (late August/September) was not covered adequately in 2011 but no other important Autumn/Winter flying bog-associated species are known to have been under-recorded. No species are known to fluctuate greatly on raised bogs from year to year due to natural factors other than flight season.

\section{Conclusion}

In summary, six species were correlated with designated raised bogs: A. monoglypha, N. pronuba, D. fascelina, A. menyanthidis S. brunnearia and M. rubi. One significant indicator species (D. fascelina) of designated raised bogs was found. Knowledge of host food plant, both adult and larval, is a useful feature of Lepidoptera, which explained the alignment of several species with site type. But, it did not provide an explanation for the association of $S$. brunnearia or D. fascelina with designated raised bogs indicating that other factors, such as habitat structural diversity may be responsible for site preference and this link should be investigated. The study suggests that D. fascelina, A. menyanthidis and S. brunnearia, bog-associated species of conservation concern, may be particularly vulnerable to the loss of active raised bog habitat.

The results show that undesignated, degraded bogs harbour bog-associated moth species of conservation concern and may have a role to play in the invertebrate conservation. To determine this, further research is required to fully describe the invertebrate fauna of these sites and of the marginal areas of designated sites. In general, differences between moth communities on designated and undesignated sites were rather subtle, but there is evidence that designated sites may be performing better than undesignated sites for some of the most important moth communities, i.e. certain bog-associated species of conservation concern.

The findings of this study also suggest that further research on potential active raised bog biodiversity indicator species should take place at a landscape scale and not just focus on designated sites. Further research should include a suite of carefully selected species or groups.

\section{Acknowledgements}

We thank Bord na Móna and An Taisce for allowing access to certain sites and Bord na Móna for providing ecological data, Padraig Comerford, Divisional Manager, NPWS, Conservation Rangers Colm Malone, Noel Bugler and Roy Thompson, for assistance with field work, Jim Ryan, NPWS Wetlands Unit for providing data on the designated bogs, Mel Conway and Michelle Molumby, NPWS GIS Unit for providing GIS spatial data sets, Professor Martin Downes, who advised on project design and Dr. Brian Nelson, NPWS and Fernando Fernandez Valverde for their helpful comments on this manuscript. We also thank the two anonymous reviewers for Insect Conservation and Diversity whose comments improved earlier versions of this manuscript.

\section{References}

Agresti, A. (1996) An introduction to Categorical Data Analysis. John Wiley \& Sons, New York City, New York. 
Altermatt, F. \& Pearse, I.S. (2011) Similarity and specialization of the larval versus adult diet of European butterflies and moths. The American Naturalist, 178, 372-382.

Beck, J., Brehm, G. \& Fiedler, K. (2011) Links between the environment, abundance and diversity of Andean moths. Biotropica, 43, 208-217.

Beck, J. \& Linsenmair, K.E. (2006) Feasibility of light-trapping in community research on moths: attraction radius of light, completeness of samples, nightly flight times and seasonality of Southeast-Asian hawkmoths (Lepidoptera: Sphingidae). Journal of Research on the Lepidoptera, 39, 18-36.

Betzholtz, P.-E. \& Franzén, M. (2011) Mobility is related to species traits in noctuid moths. Ecological Entomology, 36, 369376.

Betzholtz, P.-E. \& Franzén, M. (2013) Ecological characteristics associated with high mobility in night-active moths. Basic and Applied Ecology, 14, 271-279.

Bezděk, A., Jaroš, J. \& Spitzer, K. (2006) Spatial distribution of ground beetles (Coleoptera: Carabidae) and moths (Lepidoptera) in the Mrtvy luh bog, Sumava Mts (Central Europe): a test of habitat island community. Biodiversity and Conservation, 15, 395-409.

Bond, K.G.M. (1989) Clonmacnoise Heritage Zone, Co., Offaly, Ireland: assessment of conservation value based on Lepidoptera recorded from 1983 to 1987. Bulletin of the Irish Biogeographical Society, 12, 63-89.

Bond, K.G.M. \& Gittings, T. (2008) Database of Irish lepidoptera. 1 - Macrohabitats, microsites and traits of noctuidae and butterflies. Irish Wildlife Manuals, No. 35, 314 pp. National Parks and Wildlife Service, Department of the Environment, Heritage and Local Government, Dublin, Ireland. < http://www.npws.ie/sites/ default/files/publications/pdf/IWM35.pdf > 25th May 2013.

Bond, K., Nash, R. \& O'Connor, J.P. (2006) An Annotated Checklist of the Irish Butterflies and Moths (Lepidoptera). The Irish Biogeographical Society in association with The National Museum of Ireland, Dublin, Ireland

Burnham, K. P. \& Anderson, D. R. (2002) Model Selection and Multimodel Inference: a Practical Information-Theoretic Approach, 2nd edn. Springer-Verlag, New York City, New York.

Cardoso, P. (2012) Habitats Directive species lists: urgent need of revision. Insect Conservation and Diversity, 5, 169-174.

Conrad, K.F., Warren, M.S., Fox, R., Parsons, M.S. \& Woiwod, I.P. (2006) Rapid declines of common, widespread British moths provide evidence of an insect biodiversity crisis. Biological Conservation, 132, 279-291.

Cook, C.N., Mascia, M.B., Schwartz, M.W., Possingham, H.P. \& Fuller, R.A. (2013) Achieving conservation science that bridges the knowledge-action boundary. Conservation Biology, 27, 669678.

Council of the European Communities (1992) Council Directive of 21 May 1992 on the conservation of natural habitats and of wild fauna and flora. Official Journal of the European Communities, 35, 7-50.

Crawley, M.J. (2007) The R Book. John Wiley \& Sons, Chichester, UK

Cross, J.R. (1990) The raised bogs of Ireland: their ecology, status and conservation. Department of Finance, Dublin, Ireland. $<$ http://www.npws.ie/sites/default/files/publications/pdf/Cross_ 1990_Raised_Bogs.pdf $>$ 8th November 2015.

DAHG (2014) National Raised Bog SAC Management Plan, Draft for Consultation January 2014. Department of Arts, Heritage and the Gaeltacht. <http://www.npws.ie/peatlandsand-turf-cutting/management-plans $>$ 8th November 2015.
Davies, H., Brereton, T.M., Roy, D.B. \& Fox, R. (2007) Government targets for protected area management: will threatened butterflies benefit? Biodiversity Conservation, 16, 3719-3736.

Dévoto, M., Bailey, S. \& Memmott, J. (2011) The 'night shift': nocturnal pollen-transport networks in a boreal pine forest. Ecological Entomology, 36, 25-35.

Dise, N.B. (2009) Peatland response to global change. Science, 326, 810-811.

Dufrêne, M. \& Legendre, P. (1997) Species assemblages and indicator species: the need for a flexible asymmetrical approach. Ecological Monographs, 67, 345-366.

van Duinen, G.A. (2013) Rehabilitation of Aquatic Invertebrate Communities in Raised Bog Landscapes. PhD thesis, Radboud University, Nijmegen, the Netherlands. < http://www.ru.nl/ publish/pages $/ 664721 /$ phd_thesis_g-jvduinen.pdf $>$ 20th October 2013 .

van Duinen, G.-J., Brock, A., Kuper, J., Leuven, R., Peeters, T., Roelofs, J., van der Velde, G., Verberk, W.C. \& Esselink, H. (2003) Do restoration measures rehabilitate fauna diversity in raised bogs? A comparative study on aquatic macroinvertebrates. Wetlands Ecology and Management, 11, 447-459.

Emmet, A.M. (1991) Life history chart. The Moths and Butterflies of Great Britain and Ireland. 7(2) Lasiocampidae - Thyatiridae with Life History Chart of the British Lepidoptera (ed. by A.M. Emmet and J. Heath), pp. 61-303. Harley Books, Colchester, UK.

ESRI (2008) $\operatorname{ArcGIS}^{\circledR}$ : Version 9.3. ESRI, Redlands, California.

Fattorini, S. (2005) A simple method to fit geometric series and broken stick models in community ecology and island biogeography. Acta Oecologica, 28, 199-205.

Fernandez, F., Connolly, K., Crowley, W., Denyer, J., Duff, K. \& Smith, G. (2014) Raised Bog Monitoring and Assessment Survey 2013. Irish Wildlife Manuals, No. 81. National Parks and Wildlife Service, Department of Arts, Heritage and Gaeltacht, Dublin, Ireland. < http://www.npws.ie/sites/default/files/ publications/pdf/IWM81_0.pdf $>$ 8th November 2015.

Fernandez, F., Fanning, M., McCorry, M. \& Crowley, W. (2005a) Raised Bog Monitoring Project 2004-05. Document 1, Summary Report. National Parks \& Wildlife Service, Department of Environment, Heritage and Local Government, Dublin, Ireland. < http://www.npws.ie/sites/default/files/publications/pdf/Valverde_et_al_2005_Raised_Bog_Monitoring_-_P1_ Summary_Report.pdf $>15$ th June 2009.

Fernandez, F., Fanning, M., McCorry, M. \& Crowley, W. (2005b) Raised Bog Monitoring Project 2004-05. Document 3, Volume 3, Site Reports and Maps, National Parks and Wildlife Service, Department of Environment, Heritage and Local Government, Dublin, Ireland. <http://www.npws.ie/sites/default/files/publi cations/pdf/Valverde_et_al_2005_Raised_Bog_Monitoring_-_P3_ Site_reports_-_V3.pdf $>$ 7th December 2013.

Fernandez, F., Fanning, M., McCorry, M. \& Crowley, W. (2005c) Raised Bog Monitoring Project 2004-05. Document 3, Volume 4, Site Reports and Maps, National Parks and Wildlife Service, Department of Environment, Heritage and Local Government, Dublin, Ireland. < http://www.npws.ie/sites/default/files/publications/pdf/Valverde_et_al_2005_Raised_Bog_Monitoring_-_P3 Site_reports_-_V4.pdf $>$ 7th December 2013.

Flynn, C. (2014) Nocturnal Lepidoptera of Midland Raised Bogs. MSc. Thesis, Biology Dept. NUI Maynooth, Co. Kildare, Ireland.

Foss, P.J., O'Connell, C.A. \& Crushell, P.H. (2001) Bogs and Fens of Ireland Conservation Plan 2005. Irish Peatland Conservation Council, Dublin, Ireland. 
Fuentes-Montemayor, E., Goulson, D., Cavin, L., Wallace, J.M. \& Park, K.J. (2012) Factors influencing moth assemblages in woodland fragments on farmland: Implications for woodland management and creation schemes. Biological Conservation, 153, 265-275.

Gelbrecht, J., Sbieschne, H., Rödel, I. \& Trusch, R. (1997) Aktuelle Verbreitung und ökologische Ansprüche von Selidosema brunnearium (Villers, 1789) in der Mark Brandenburg und in der angrenzenden Oberlausitz (Lep., Geometridae). Zur Faunistik und Ökologie der Schmetterlinge in der Mark Brandenburg IX. Entomologische Nachrichten und Berichte, 41, 121-124.

Giller, P.S. (1984) Community Structure and the Niche. Chapman and Hall, London, UK.

Guisan, A., Edwards, T.C. \& Hastie, T. (2002) Generalised linear and generalised additive models in studies of species distributions: setting the scene. Ecological Modelling, 157, 89-100.

Hammond, R.F. (1981) The Peatlands of Ireland. 2nd edn. Soil Survey Bulletin, No. 35, An Foras Talúntais, Dublin, Ireland.

Hannigan, E. \& Kelly-Quinn, M. (2012) Composition and structure of macroinvertebrate communities in contrasting openwater habitats in Irish peatlands: implications for biodiversity conservation. Hydrobiologia, 692, 19-28.

Heath, J. (1965) A genuinely portable MV light trap. Entomologists' Record and Journal of Variation, 77, 236-238.

Hernandez-Manrique, O.L., Numa, C., Verdu, J.R., Galante, E. \& Lobo, J.M. (2012) Current protected sites do not allow the representation of endangered invertebrates: the Spanish case. Insect Conservation and Diversity, 5, 414-421.

Hunter, M.L. (2005) A mesofilter conservation strategy to complement fine and coarse filters. Conservation Biology, 19, 10251029.

Jonason, D., Franzén, M. \& Ranius, T. (2014) Surveying moths using light traps: effects of weather and time of year. PLoS ONE, 9, e92453. doi:10.1371/journal.pone. 0092453

Jones, H.E. \& Etherington, J.R. (1970) Comparative studies of plant growth and distribution in relation to waterlogging: I the survival of Erica cinerea L. and E. Tetralix L. and its apparent relationship to iron and manganese uptake in waterlogged soil. Journal of Ecology, 58, 487-496.

Karsholt, O. \& van Nieukerken, E.J. (2013) Lepidoptera, Moths. Fauna Europaea version 2.6.2 <http://www.faunaeur.org $>$ 29th October 2014.

Kelly, L. (1993) Hydrology, Hydrochemistry and Vegetation of Two Raised Bogs in Co. Offaly, Ph.D. Thesis. Trinity College, Dublin, Ireland. <http://www.npws.ie/sites/default/files/publications/pdf/Kelly_1993 Clara and Raheenmore Bog.pdf $>$ 25th February 2009.

Kelly, L., Doak, M. \& Dromey, M. (1995) Raised Bog Restoration Project: An Investigation into the Conservation and Restoration of Selected Raised Bog Sites in Ireland. Part 1 Summary Reports. National Parks \& Wildlife Service, Department of Environment, Heritage and Local Government, Dublin. $<$ http://www.npws.ie/sites/default/files/publications/pdf/Kelly_ et_al 1995_Bog_Restoration_P1.pdf > 7th December 2013.

Kelly, L. \& Schouten, M.G.C. (2002) Vegetation. Conservation and Restoration of Raised Bogs: Geological, Hydrological and Ecological Studies (ed. by M.G.C. Schouten) pp. 110-169. Dúchas - The Heritage Service of the Department of Environment and Local Government, Dublin, Ireland; Staatsbosbeheer, The Netherlands; Geological Survey of Ireland, Dublin, Ireland.

Krebs, C.J. (1999) Ecological Methodology, 2nd edn. Addison Wesley Longman, New York City, New York.
Limpens, J., Berendse, F., Canadell, J.G., Freeman, C., Holden, J., Roulet, N., Rydin, H. \& Schaepman-Strub, G. (2008) Peatlands and the carbon cycle: from local processes to global implications - a synthesis. Biogeosciences, 5, 1475-1491.

MacArthur, R.H. (1957) On the relative abundance of bird species. Proceedings of the National Academy of Sciences, USA, 43, 293-295.

MacArthur, R.H. \& Wilson, E.O. (1967) The Theory of Island Biogeography. Princeton University Press, Princeton, New Jersey.

Magurran, A.E. (2004) Measuring Biological Diversity. Blackwell Publishing, Oxford, UK.

Marmion, M., Luoto, M., Heikkinen, R.K. \& Thuiller, W (2009) The performance of state-of-the-art modelling techniques depends on geographical distribution of species. Ecological Modelling, 220, 3512-3520.

Matthews, T.J. \& Whittaker, R.J. (2015) On the species abundance distribution in applied ecology and biodiversity management. Journal of Applied Ecology, 52, 443-454.

Mazei, Y.A. \& Tsyganov, A.N. (2007) Species composition, spatial distribution and seasonal dynamics of testate amoebae community in a sphagnum bog (Middle Volga region, Russia). Protistology, 5, 156-206.

Mazerolle, M.J. (2006) Improving data analysis in herpetology: using Akaike's Information Criterion (AIC) to assess the strength of biological hypotheses. Amphibia-Reptilia, 27, 169180 .

McCullagh, P. \& Nelder, J. (1989) Generalized Linear Models. Chapman and Hall, London, UK.

McCune, B. \& Grace, J.B. (2002) Analysis of Ecological Communities. MjM Software Design, Gleneden Beach, Oregan.

McCune, B. \& Mefford, M.J. (2011) PC-ORD. Multivariate Analysis of Ecological Data. Version 6. MjM Software, Gleneden Beach, Oregon.

McGeoch, M.A. (1998) The selection, testing and application of terrestrial insects as bioindicators. Biological Reviews, 73, 181201.

Mitchell, F. (1990) Shell Guide to Reading the Irish Landscape. Country House, Dublin, Ireland.

Nolan, M. (2013) Spiders (Araneae) of Irish raised bogs: Clara bog, Co. Offaly and Carrowbehy bog, Co. Roscommon. Bulletin of the Irish Biogeographical Society, 37, 172-203.

NPWS (2013) The status of EU Protected Habitats and Species in Ireland. Overview, (ed. by D. Lynn), Vol. 1, p. 51 .Unpublished Report. National Parks and Wildlife Service, Department of Arts, Heritage and the Gaeltacht, Dublin, Ireland. < http:// www.npws.ie/sites/default/files/publications/pdf/Art17-Vol1-web. pdf > 10th April 2015.

O’Neill, B., Bond, K, Tyner, A., Sheppard, R., Bryant, T., Chapman, J., Bell, J. \& Donnelly, A. (2012) Climate change is advancing the phenology of moth species in Ireland. Entomologia Experimentalis et Applicata, 143, 74-88.

Oxbrough, A., French, V., Irwin, S., Kelly, T.C., Smiddy, P. \& O'Halloran, J. (2012) Can mixed species stands enhance arthropod diversity in plantation forests? Forest Ecology and Management, 270, 11-18.

Peck, J.E. (2010) Multivariate Analysis for Community Ecologists: Step by Step Using PC-ORD. MJM Software Design, Gleneden Beach, Oregon.

R Development Core Team (2013) CRAN R Library repository. $<$ http://cran.r-project.org/ > 9th June 2015.

Renou-Wilson, F., Bolger, T., Bullock, C., Convery, F., Curry, J. P., Ward, S., Wilson, D. \& Müller, C. (2011) BOGLAND - 
Sustainable Management of Peatlands in Ireland. pp. 181. STRIVE Report No 75. Prepared for the Environmental Protection Agency, Johnstown Castle, Co. Wexford. < http://erc.epa.ie/safer/reports > 10th January 2012.

Sauberer, N., Zulka, K.P., Abensperg-Traun, M., Berg, H.M., Bieringer, G., Milasowszky, N., Moser, D., Plutzar, C., Pollheimer, M., Storch, C., Trostl, R., Zechmeister, H. \& Grabherr, G. (2004) Surrogate taxa for biodiversity in agricultural landscapes of eastern Austria. Biological Conservation, 117, 181-190.

Savage, J., Wheeler, T.A., Moores, A.M.A. \& Taillefer, A.G. (2011) Effects of habitat size, vegetation cover, and surrounding land use on Diptera diversity in temperate nearctic bogs. Wetlands, 31, 125-134.

van der Schaaf, S. (2002) Bog types, climate and land forms. Conservation and Restoration of Raised Bogs. Geological, Hydrological and Ecological Studies (ed. by M.G.C. Schouten), pp 11-15. Dúchas - The Heritage Service of the Department of Environment and Local Government, Dublin, Ireland; Staatsbosheer, The Netherlands; Geological Survey of Ireland, Dublin, Ireland.

Schouten, M.G.C., Streefkerk, J.G. \& van der Molen, P.C. (1992) Impact of climatic change on bog ecosystems, with special reference to sub-oceanic raised bogs. Wetlands Ecology and Management, 2, 55-61.

Skinner, B. (2009) Colour Identification Guide to Moths of the British Isles. Apollo Books, Stenstrup, Denmark.

Slade, E.M., Merckx, T., Riutta, T., Bebber, D.P., Redhead, D., Riordan, P. \& Macdonald, D.W. (2013) Life-history traits and landscape characteristics predict macro-moth responses to forest fragmentation. Ecology, 94, 1519-1530.

Speight, M.C.D. (1986) Criteria for the selection of insects to be used as bio-indicators in nature conservation research. Proc.3rd. Eur. Cong. Ent., Amsterdam, pt, 3, 485-488.

Speight, M.C.D., Castella, E. \& Obrdlik, P. (2002) Macrohabitat preferences of European Syrphidae (Diptera). Syrph the Net, the database of European Syrphidae (ed. by M.C.D. Speight, E.
Castella, P. Obrdlik and S. Ball), Vol 33, p. 478. Syrph the Net publications, Dublin, Ireland.

Spitzer, K. \& Danks, H.V. (2006) Insect biodiversity of boreal peat bogs. Annual Review of Entomology, 51, 137-161.

Truxa, C. \& Fiedler, K. (2012) Attraction to light - from how far do moths (Lepidoptera) return to weak artificial sources of light? European Journal of Entomology, 109, 77-84.

Tyner, A. (2014) MothsIreland, Mapping Ireland's Moths. $<$ http://www.mothsireland.com $>$ 8th November 15.

Väisänen, R. (1992) Distribution and abundance of diurnal lepidoptera on a raised bog in Southern Finland. Ann. Zool. Fennici, 29(2), 75-92.

Van Dyck, H. \& Baguette, M. (2005) Dispersal behaviour in fragmented landscapes: routine or special movements? Basic and Applied Ecology, 6, 535-545.

Waring, P. \& Townsend, M. (2009) Field Guide to the Moths of Great Britain and Ireland. British Wildlife Publishing, Gillingham, UK.

Webb, N.R. (1989) Studies on the invertebrate fauna of fragmented heathland in Dorset, UK, and the implications for conservation. Biological Conservation, 47, 153-165.

Williams, C.D., Hayes, M., McDonnell, R.J., Anderson, R., Bleasdale, A. \& Gormally, M.J. (2014) Factors affecting wetland ground beetle (Carabidae) assemblages: how important are habitats, conservation designations and management? Insect Conservation \& Diversity, 7, 206-222.

Winfree, R., Dushoff, J., Crone, E.E., Schultz, C.B., Budny, R.V., Williams, N.M. \& Kremen, C. (2005) Testing simple indices of habitat proximity. American Naturalist, 165, 707-717.

Accepted 29 February 2016

First published online 23 April 2016

Editor: Alan Stewart

Associate editor: Peter Dennis

Appendix 1 List of moth species recorded in the study.

\begin{tabular}{|c|c|c|c|c|c|}
\hline Abbreviation & Scientific Name and Authority & Common Name & $\begin{array}{l}\text { Habitat } \\
\text { Association }\end{array}$ & $\begin{array}{l}\text { Conservation } \\
\text { Status }\end{array}$ & Total no. \\
\hline ACROMENY & Acronicta menyanthidis (Esper, 1789) & Light Knot Grass & Raised bog & Rare & 3 \\
\hline AGROCIRC & Agrochola circellaris (Hufnagel, 1766) & Brick & Other & Declining & 3 \\
\hline AGROEXCL & Agrotis exclamationis (Linnaeus, 1758) & Heart and Dart & Other & & 9 \\
\hline AGROHELV & Agrochola helvola (Linnaeus, 1758) & Flounced Chestnut & Raised bog & Declining & 1 \\
\hline AGROLOTA & Agrochola lota (Clerck, 1759) & Red-line Quaker & Other & & 3 \\
\hline AGROLYCH & $\begin{array}{l}\text { Agrochola lychnidis (Denis \& } \\
\text { Schiffermüller, 1775) }\end{array}$ & Beaded Chestnut & Other & Vulnerable & 1 \\
\hline AGROMACI & Agrochola macilenta (Hübner, 1809) & Yellow-line Quaker & Raised bog & & 1 \\
\hline ALCIREPA & Alcis repandata (Linnaeus, 1758) & Mottled Beauty & Raised bog & & 3 \\
\hline ALLOOXYA & Allophyes oxyacanthae (Linnaeus, 1758) & Green-brindled Crescent & Other & Vulnerable & 2 \\
\hline AMPH (agg.) & Amphipoea agg. & Ear species & Raised bog & & 27 \\
\hline APAMMONO & Apamea monoglypha (Hufnagel, 1766) & Dark Arches & Raised bog & & 225 \\
\hline APAMREMI & Apamea remissa (Hübner, 1809) & Dusky Brocade & Other & Vulnerable & 4 \\
\hline APLOPLAG & Aplocera plagiata (Linnaeus, 1758) & Treble-bar & Other & Declining & 4 \\
\hline APORNIGR & Aporophyla nigra (Haworth, 1809) & Black Rustic & Raised bog & & 12 \\
\hline ARCTCAJA & Arctia caja (Linnaeus, 1758) & Garden Tiger & Raised bog & Vulnerable & 22 \\
\hline AUTOGAMM & Autographa gamma (Linnaeus, 1758) & Silver Y & Other & & 2 \\
\hline AUTOJOTA & Autographa jota (Linnaeus, 1758) & Plain Golden Y & Other & & 2 \\
\hline BISTBETU & Biston betularia (Linnaeus, 1758) & Peppered Moth & Other & & 1 \\
\hline CABEEXAN & Cabera exanthemata (Scopoli, 1763) & Common Wave & Other & & 1 \\
\hline
\end{tabular}


Appendix 1. (Continued)

\begin{tabular}{|c|c|c|c|c|c|}
\hline Abbreviation & Scientific Name and Authority & Common Name & $\begin{array}{l}\text { Habitat } \\
\text { Association }\end{array}$ & $\begin{array}{l}\text { Conservation } \\
\text { Status }\end{array}$ & Total no. \\
\hline CELAHAWO & Celaena haworthii (Curtis, 1829) & Haworth's Minor & Raised bog & Vulnerable & 1 \\
\hline CERAPISI & Ceramica pisi (Linnaeus, 1758) & Broom Moth & Raised bog & Vulnerable & 8 \\
\hline CHLOSITE & Chloroclysta siterata (Hufnagel, 1767) & Red-green Carpet & Other & & 1 \\
\hline CHLOV-AT & Chloroclystis v-ata (Haworth, 1809) & V-pug & Other & & 2 \\
\hline CILIGLAU & Cilix glaucata (Scopoli, 1763) & Chinese Character & Other & & 2 \\
\hline CLEOLICH & Cleorodes lichenaria (Hufnagel, 1767) & Brussels Lace & Raised bog & & 2 \\
\hline COSMOCEL & Cosmorhoe ocellata (Linnaeus, 1758) & Purple Bar & Other & & 1 \\
\hline CROCELIN & Crocallis elinguaria (Linnaeus, 1758) & Scalloped Oak & Other & & 3 \\
\hline DEILELPE & Deilephila elpenor (Linnaeus, 1758) & Elephant Hawk-moth & Raised bog & & 2 \\
\hline DELTPYGA & $\begin{array}{l}\text { Deltote (Protodeltote) pygarga } \\
\text { (Hufnagel, 1766) }\end{array}$ & Marbled White Spot & Raised bog & & 1 \\
\hline DENTPYGM & Denticucullus pygmina (Haworth, 1809) & Small Wainscot & Raised bog & & 2 \\
\hline DIACCHRY & Diachrysia chrysitis (Linnaeus, 1758) & Burnished Brass & Other & & 1 \\
\hline DIARMEND & Diarsia mendica (Fabricius, 1775) & Ingrailed Clay & Raised bog & & 1 \\
\hline DICAFASC & Dicallomera fascelina (Linnaeus, 1758) & Dark Tussock & Raised bog & Rare & 27 \\
\hline DREPFALC & Drepana falcataria (Linnaeus, 1758) & Pebble Hook-tip & Other & & 2 \\
\hline DYSCFAGA & Dyscia fagaria (Thunberg, 1784) & Grey Scalloped Bar & Raised bog & Scarce & 65 \\
\hline EILEDEPR & Eilema depressa (Esper, 1787) & Buff Footman & Raised bog & & 3 \\
\hline EILELURI & Eilema lurideola (Zincken, 1817) & Common Footman & Raised bog & & 25 \\
\hline ENNOALNI & Ennomos alniaria (Linnaeus, 1758) & Canary-shouldered Thorn & Other & & 3 \\
\hline EUGNGLAR & Eugnorisma glareosa (Esper, 1788) & Autumnal Rustic & Raised bog & Endangered & 4 \\
\hline EULITEST & Eulithis testata (Linnaeus, 1761) & Chevron & Raised bog & & 3 \\
\hline EUPINANA & Eupithecia nanata (Hübner, 1813) & Narrow-winged Pug & Raised bog & & 19 \\
\hline EUTHPOTA & Euthrix potatoria (Linnaeus, 1758) & Drinker & Raised bog & & 2 \\
\hline FALCLACE & Falcaria lacertinaria (Linnaeus, 1758) & Scalloped Hook-tip & Other & Declining & 11 \\
\hline GEOMPAPI & Geometra papilionaria (Linnaeus, 1758) & Large Emerald & Other & & 1 \\
\hline GRAPAUGU & Graphiphora augur (Fabricius, 1775) & Double Dart & Other & Endangered & 2 \\
\hline GRIPAPRI & Griposia aprilina (Linnaeus, 1758) & Merveille du Jour & Other & & 1 \\
\hline GYMNRUFI & Gymnoscelis rufifasciata (Haworth, 1809) & Double-striped Pug & Raised bog & & 3 \\
\hline HABRPYRI & Habrosyne pyritoides (Hufnagel, 1766) & Buff Arches & Other & & 2 \\
\hline HELOLEUC & Helotropha leucostigma (Hübner, 1808) & Crescent & Other & Vulnerable & 2 \\
\hline HYDRMICA & Hydraecia micacea (Esper, 1789) & Rosy Rustic & Other & Vulnerable & 2 \\
\hline HYDRFURC & Hydriomena furcata (Thunberg, 1784) & July Highflyer & Raised bog & & 5 \\
\hline IDAEAVER & Idaea aversata (Linnaeus, 1758) & Riband Wave & Raised bog & & 8 \\
\hline IDAEDIMI & Idaea dimidiata (Hufnagel, 1767) & Single-dotted Wave & Other & & 1 \\
\hline LAOTPOPU & Laothoe populi (Linnaeus, 1758) & Poplar Hawk-moth & Other & & 13 \\
\hline LASIQUER & $\begin{array}{l}\text { Lasiocampa (Lasiocampa) quercus } \\
\text { (Linnaeus, 1758) }\end{array}$ & Oak Eggar & Raised bog & & 8 \\
\hline LITHORNI & $\begin{array}{l}\text { Lithophane (Lithophane) ornitopus } \\
\text { (Hufnagel, 1766) }\end{array}$ & Grey Shoulder-knot & Other & & 1 \\
\hline LOMAMARG & Lomaspilis marginata (Linnaeus, 1758) & Clouded Border & Other & & 1 \\
\hline LYCOPORP & $\begin{array}{l}\text { Lycophotia porphyrea (Denis \& } \\
\text { Schiffermüller, 1775) }\end{array}$ & True Lover's Knot & Raised bog & & 947 \\
\hline MACRRUBI & Macrothylacia rubi (Linnaeus, 1758) & Fox Moth & Raised bog & & 7 \\
\hline MESASECA & Mesapamea agg. & Common Rustic agg. & Raised bog & & 9 \\
\hline MESODIDY & Mesotype didymata (Linnaeus, 1758) & Twin-spot Carpet & Raised bog & & 1 \\
\hline MNIOADUS & Mniotype adusta (Esper, 1790) & Dark Brocade & Raised bog & Vulnerable & 1 \\
\hline MYTHIMPU & Mythimna impura (Hübner, 1808) & Smoky Wainscot & Raised bog & & 8 \\
\hline MYTHPALL & Mythimna pallens (Linnaeus, 1758) & Common Wainscot & Other & & 1 \\
\hline MYTHPUDO & $\begin{array}{l}\text { Mythimna pudorina (Denis \& } \\
\text { Schiffermüller, 1775) }\end{array}$ & Striped Wainscot & Raised bog & Scarce & 1 \\
\hline NOCTCOME & Noctua comes (Hübner, 1813) & Lesser Yellow Underwing & Raised bog & & 5 \\
\hline NOCTPRON & Noctua pronuba (Linnaeus, 1758) & Large Yellow Underwing & Raised bog & & 103 \\
\hline NONATYPH & Nonagria typhae (Thunberg, 1784) & Bulrush Wainscot & Other & & 2 \\
\hline NOTOZICZ & Notodonta ziczac (Linnaeus, 1758) & Pebble Prominent & Other & & 9 \\
\hline NUDAMUND & Nudaria mundana (Linnaeus, 1761) & Muslin Footman & Raised bog & & 2 \\
\hline OPISLUTE & Opisthograptis luteolata (Linnaeus, 1758) & Brimstone Moth & Other & & 5 \\
\hline
\end{tabular}


Appendix 1. (Continued)

\begin{tabular}{|c|c|c|c|c|c|}
\hline Abbreviation & Scientific Name and Authority & Common Name & $\begin{array}{l}\text { Habitat } \\
\text { Association }\end{array}$ & $\begin{array}{l}\text { Conservation } \\
\text { Status }\end{array}$ & Total no. \\
\hline OURASAMB & Ourapteryx sambucaria (Linnaeus, 1758) & Swallow-tailed Moth & Other & & 2 \\
\hline PENNFIRM & Pennithera firmata (Hübner, 1822) & Pine Carpet & Other & & 3 \\
\hline PERCSTRI & Perconia strigillaria (Hübner, 1787) & Grass Wave & Raised bog & & 10 \\
\hline PHALBUCE & Phalera bucephala (Linnaeus, 1758) & Buff-tip & Other & & 3 \\
\hline PHARFUSC & Pharmacis fusconebulosa (DeGeer, 1778) & Map-winged Swift & Other & & 18 \\
\hline PHEOGNOM & Pheosia gnoma (Fabricius, 1776) & Lesser Swallow Prominent & Other & & 7 \\
\hline PHLOMETI & Phlogophora meticulosa (Linnaeus, 1758) & Angle Shades & Raised bog & & 22 \\
\hline PHRAFULI & Phragmatobia fuliginosa (Linnaeus, 1758) & Ruby Tiger & Raised bog & & 2 \\
\hline PLUSFEST & Plusia festucae (Linnaeus, 1758) & Gold Spot & Raised bog & & 1 \\
\hline RHIZLUTO & Rhizedra lutosa (Hübner, 1803) & Large Wainscot & Other & Vulnerable & 3 \\
\hline RIVUSERI & Rivula sericealis (Scopoli, 1763) & Straw Dot & Raised bog & & 1 \\
\hline SELIBRUN & Selidosema brunnearia (de Villers, 1789) & Bordered Grey & Raised bog & Scarce & 32 \\
\hline SPILLUBR & Spilosoma lubricipeda (Linnaeus, 1758) & White Ermine & Raised bog & Vulnerable & 6 \\
\hline SUBAMEGA & $\begin{array}{l}\text { Subacronicta megacephala (Denis \& } \\
\text { Schiffermüller, 1775) }\end{array}$ & Poplar Grey & Other & Scarce & 3 \\
\hline SYNGINTE & Syngrapha interrogationis (Linnaeus, 1758) & Scarce Silver Y & Raised bog & Scarce & 3 \\
\hline THERBRIT & Thera britannica (Turner, 1925) & Spruce Carpet & Other & & 16 \\
\hline THEROBEL & Thera obeliscata (Hübner, 1787) & Grey Pine Carpet & Other & & 1 \\
\hline THUMSENE & Thumatha senex (Hübner, 1808) & Round-winged Muslin & Raised bog & & 1 \\
\hline XANTFERR & Xanthorhoe ferrugata (Clerck, 1759) & Dark-barred Twin-spot Carpet & Raised bog & Endangered & 2 \\
\hline XESTAGAT & Xestia agathina (Duponchel, 1827) & Heath Rustic & Raised bog & Vulnerable & 4 \\
\hline XESTC-NI & Xestia c-nigrum (Linnaeus, 1758) & Setaceous Hebrew Character & Other & & 6 \\
\hline XESTTRIA & Xestia triangulum (Hufnagel, 1766) & Double Square-spot & Other & & 2 \\
\hline
\end{tabular}

Appendix 2 List of explanatory variables used in the NMS ordination

\begin{tabular}{llllr}
\hline & $\begin{array}{l}\text { Minimum distance } \\
\text { to edge of high bog (m) }\end{array}$ & Area of high bog (ha) & Drain density & Connectivity (C) \\
\hline Sharavogue & 220 & 137.02 & 0.01599 & 22.64 \\
Mongan & 376 & 124.37 & 0.00748 & 17.03 \\
Ferbane & 123 & 119.98 & 0.00908 & 9.55 \\
Moyclare & 253 & 74.27 & 0.00512 & 7.49 \\
Clara west & 496 & 246.78 & 0.00071 & 32.77 \\
Raheenmore & 385 & 130.55 & 0.00720 & 12.96 \\
Old Croghan & 350 & 95.12 & 0.03924 & 11.47 \\
Clonaltra & 151 & 578.14 & 0.04637 & 35.57 \\
Curraghalassa & 238 & 65.42 & 0.04181 & 24.19 \\
Doon & 127 & 47.76 & 0.01048 & 0.04939 \\
Clonlyon & 390 & 88.65 & 0.06112 & 37.99 \\
Kilballyskea & 272 & 40.64 & & 22.41 \\
\hline
\end{tabular}

